\title{
1 Enhanced canopy growth precedes senescence in 2005 and 2010 Amazonian droughts
}

2 Yi Y. Liu ${ }^{1 *}$, Albert I.J.M. van Dijk ${ }^{2}$, Diego G. Miralles ${ }^{3}$, Matthew F. McCabe ${ }^{4}$, Jason P. Evans ${ }^{5}$,

3 Richard A.M. de Jeu ${ }^{6}$, Pierre Gentine ${ }^{7}$, Alfredo Huete ${ }^{8}$, Robert M. Parinussa ${ }^{1}$, Lixin Wang ${ }^{9}$,

$4 \quad$ Kaiyu Guan ${ }^{10}$, Joe Berry ${ }^{11}$, Natalia Restrepo-Coupe ${ }^{8}$

$5{ }^{1}$ School of Geographical Sciences, Nanjing University of Information Science and Technology,

$6 \quad$ Nanjing, 210044, China.

$7{ }^{2}$ Fenner School of Environment \& Society, Australian National University, Canberra,

8 Australian Capital Territory 0200, Australia.

$9 \quad{ }^{3}$ Laboratory of Hydrology and Water Management, Ghent University, Ghent 9000, Belgium.

${ }^{4}$ Division of Biological and Environmental Sciences and Engineering, King Abdullah

University of Science and Technology, Thuwal 23955-6900, Saudi Arabia.

${ }^{5}$ ARC Centre of Excellence for Climate Extremes \& Climate Change Research Centre,

University of New South Wales, Sydney, New South Wales 2052, Australia.

${ }^{6}$ VanderSat B.V., Wilhelminastraat 43A, 2011 VK, Haarlem, Netherlands.

${ }^{7}$ Department of Earth and Environmental Engineering and Earth Institute, Columbia University, New York, NY 10027, USA.

$17{ }^{8}$ Climate Change Cluster (C3), University of Technology Sydney, Sydney, New South Wales 2007, Australia.

${ }^{9}$ Department of Earth Sciences, Indiana University-Purdue University Indianapolis (IUPUI), Indianapolis, Indiana 46202, USA.

This is the author's manuscript of the article published in final edited form as:

Liu, Y. Y., van Dijk, A. I. J. M., Miralles, D. G., McCabe, M. F., Evans, J. P., de Jeu, R. A. M., ... RestrepoCoupe, N. (2018). Enhanced canopy growth precedes senescence in 2005 and 2010 Amazonian droughts. Remote Sensing of Environment, 211, 26-37. https://doi.org/10.1016/j.rse.2018.03.035 
$21{ }^{10}$ Department of Natural Resources and Environmental Sciences and National Center for

22 Supercomputing Applications, University of Illinois at Urbana Champaign, Urbana, Illinois 23 61801, USA

$24{ }^{11}$ Department of Global Ecology, Carnegie Institution of Washington, 260 Panama Street

25 Stanford, California 94305, USA

26 Corresponding author:

$27 \quad$ Yi Y. Liu

$28 \quad$ yiliu001@gmail.com

$29+86-25-58235190$

30

31

32 


\section{Abstract}

Unprecedented droughts hit southern Amazonia in 2005 and 2010, causing a sharp increase in tree mortality and carbon loss. To better predict the rainforest's response to future droughts, it is necessary to understand its behavior during past events. Satellite observations provide a practical source of continuous observations of Amazonian forest. Here we used a passive microwave-based vegetation water content record (i.e., vegetation optical depth, VOD), together with multiple hydrometeorological observations as well as conventional satellite vegetation measures, to investigate the rainforest canopy dynamics during the 2005 and 2010 droughts. During the onset of droughts in the wet-to-dry season (May-July) of both years, we found large-scale positive anomalies in VOD, leaf area index (LAI) and enhanced vegetation index (EVI) over the southern Amazonia. These observations are very likely caused by enhanced canopy growth. Concurrent below-average rainfall and above-average radiation during the wet-to-dry season can be interpreted as an early arrival of normal dry season conditions, leading to enhanced new leaf development and ecosystem photosynthesis, as supported by field observations. Our results suggest that further rainfall deficit into the subsequent dry season caused water and heat stress during the peak of 2005 and 2010 droughts (August-October) that exceeded the tolerance limits of the rainforest, leading to widespread negative VOD anomalies over the southern Amazonia. Significant VOD anomalies were observed mainly over the western part in 2005 and mainly over central and eastern parts in 2010. The total area with significant negative VOD anomalies was comparable between these two drought years, though the average magnitude of significant negative VOD anomalies was greater in 2005. This finding broadly agrees with the field 
observations indicating that the reduction in biomass carbon uptake was stronger in 2005 than

2010. The enhanced canopy growth preceding drought-induced senescence should be taken into account when interpreting the ecological impacts of Amazonian droughts.

\section{Keywords:}

Amazonian Droughts, Canopy Water Content, Satellite, Passive Microwave, Soil Water

Deficit, Surface Temperature, Vapor Pressure Deficit

(1)

3

(1)

67

\section{8} 69

\section{0} 71 


\section{Introduction}

The Amazonian rainforest plays a critical role in the global hydrological and carbon cycles (Pan et al., 2011). However, over the last decades, droughts over Amazonia have intensified (Marengo \& Espinoza, 2016), with a once-in-a-century drought in 2005 followed by even more severe droughts in 2010 (Lewis et al., 2011) and 2015 (Jiménez-Muñoz et al., 2016). These large-scale droughts resulted in unprecedented low river discharges (Xu et al., 2011), increased tree mortality (Phillips et al., 2009) and a reversal of a large and long-term net carbon uptake (Doughty et al., 2015, Feldpausch et al., 2016, Gatti et al., 2014, Lewis et al., 2011).

To better anticipate Amazonian rainforest response to severe droughts in the future and the associated influence on the carbon cycle, it is important to characterize and understand its forest dynamic behavior during the 2005 and 2010 droughts. A long-term research network,

RAINFOR, has been monitoring more than 100 forest plots across Amazonia over several decades. These field observations suggest that increased tree mortality in 2005 was the main cause for reduced carbon uptake and was strongly related to drought severity (Phillips et al., 2009). In the 2010 drought, Feldpausch et al. (2016) found that a combination of increased tree mortality and slow tree growth was the primary reason for reduced carbon uptake, but the distribution of increased tree mortality in 2010 seemed unrelated to local precipitation anomalies and independent of local pre-2010 drought history. Furthermore, rainfall deficit in 2010 occurred over a larger area than in 2005 (Phillips et al., 2009), but the overall reduction in carbon uptake was greater in 2005 (Feldpausch et al., 2016). Comparing the hydrometeorological conditions and forest dynamics in 2005 and 2010 should contribute to a 
better understanding of different Amazonian rainforest responses during these two droughts.

In addition to field studies, vegetation properties derived by different remote sensing techniques have also been used to investigate Amazonian rainforest responses during the two droughts. Two vegetation indices derived from the optical Moderate Resolution Imaging Spectroradiometer (MODIS), the Normalized Difference Vegetation Index (NDVI) and the Enhanced Vegetation Index (EVI), have extensively been used to characterize rainforest canopy greenness. Widespread below-average canopy greenness was observed in the dry season (July-September) during the 2010 drought from NDVI and EVI (Atkinson et al., 2011, Xu et al., 2011), but there is debate about the canopy greenness anomalies in the 2005 dry season (Saleska et al., 2007, Samanta et al., 2010). Interpretation of these optical sensor observations is challenging as they are strongly influenced by sun-sensor geometry changes and atmospheric effects, e.g., clouds and aerosols (Morton et al., 2014, Saleska et al., 2016, Samanta et al., 2010). Over southern Amazonia, the aerosol concentration was extremely high during the 2005 and 2010 dry season due to large-scale biomass burning (Ten Hoeve et al., 2012), which makes it difficult to obtain reliable optical sensor observations of the vegetation canopy.

Satellite-based sun-induced chlorophyll fluorescence (SIF) and active microwave (i.e., radar) observations were also explored to understand Amazon drought responses (Lee et al., 2013b, Saatchi et al., 2012). Lee et al. (2013b) utilized the SIF measured by the Greenhouse gases Observing SATallite (GOSAT) launched in January 2009. SIF was reduced by $15 \%$ across Amazonia during the extended dry season of 2010 compared with the non-drought year 2009. Saatchi et al. (2012) used the radar backscatter at microwave frequency $(13.4 \mathrm{GHz})$ from the 
SeaWinds Scatterometer onboard QuickSCAT (QSCAT, launched in June 1999 and deactivated in November 2009). An advantage of active microwave sensor observations is that they are minimally affected by clouds and aerosols. They found a strong negative anomaly in the radar backscatter over southwestern Amazonia during the 2005 drought, indicating impacts on the canopy structure and a decline in canopy moisture. Despite the importance of these studies, neither covers both the 2005 and 2010 droughts.

The passive microwave-based vegetation optical depth (VOD) (Owe et al., 2001), derived from 6.9 GHz observations by the Advanced Microwave Scanning Radiometer - Earth Observing System (AMSR-E, June 2002 - October 2011) onboard NASA's Aqua Satellite, covers both 2005 and 2010 droughts, and can represent the canopy water content dynamics over closed-canopy Amazonian rainforest, including leaf and branches components (Andela et al., 2013, Jones et al., 2013, Liu et al., 2015). The advantages of passive microwave-based VOD include that the signal remains sensitive to variations at a relatively high biomass density (Zhou et al., 2014); that, similarly to radar, it is minimally affected by clouds and aerosols, which are very frequent in Amazonia; and that it is less affected by sun-sensor geometry issues, as it relies on natural microwave emission from the Earth rather than reflected sunlight.

The field observations suggest the mechanisms for reduced carbon uptake in rainforests were different in 2005 and 2010 droughts (Feldpausch et al., 2016). Therefore, the primary objective of this study is to analyze the spatiotemporal evolution of these two droughts based on the passive microwave-based AMSR-E VOD and a series of satellite-based hydrometerological observations and identify their unique characteristics to better understand the similarities and differences in Amazonian rainforest responses between 2005 and 2010 events. Specifically, the 
rainforest canopy anomalies from satellite observations during both droughts are investigated together with the hydrometeorological variables over the extended dry season (May - October), which covers both the drought onset and peak periods.

\section{Materials and Methods}

\subsection{Satellite-based datasets}

We utilized several independent sources of satellite data to characterize vegetation and hydrometeorological dynamics over Amazonia (see Table 1). All data cover the same period from January 2003 through December 2010. The focus is on the dynamics of intact rainforest during 2005 and 2010 droughts. The $0.05^{\circ}$ MODIS land cover product (MCD12C1, v051) based on the International Geosphere-Biosphere Programme (IGBP) classification scheme (Friedl et al., 2010) for the year 2010 was used to delineate the spatial distribution of Amazonian forests (see Fig. 1a).

A new source of vegetation data used here is the passive microwave-based vegetation optical depth (VOD) at $0.10^{\circ}$ spatial resolution. The VOD data were obtained based on brightness temperature derived from C-band $(6.9 \mathrm{GHz})$ and Ka-band $(36.5 \mathrm{GHz})$ observations by the Advanced Microwave Scanning Radiometer - Earth Observing System (AMSR-E) onboard the Aqua satellite. These were retrieved using the Land Parameter Retrieval Model (LPRM) (Meesters et al., 2005, Owe et al., 2008, Owe et al., 2001). The smoothing filter-based intensity modulation (SFIM) approach was utilized to downscale brightness temperature to $0.10^{\circ}$ spatial resolution (Santi, 2010), and then the downscaled brightness temperature was used as the input to LPRM (de Jeu et al., 2014, Parinussa et al., 2014). The VOD is a 
dimensionless variable and can be interpreted as being directly proportional to the total vegetation water content, but varying with wavelength, vegetation structure and viewing angle (Jackson \& Schmugge, 1991, Kerr \& Njoku, 1990, Kirdyashev et al., 1979). Over closed canopy rainforest, the C-band VOD retrievals can be assumed to represent water content dynamics at the canopy level, including the leaves and branches (Guglielmetti et al., 2007, Jones et al., 2011, Jones et al., 2014).

An important assumption in the LPRM approach is that canopy surface temperature is equal to soil surface temperature (Meesters et al., 2005, Owe et al., 2008, Owe et al., 2001). The minimal temperature gradients during the night are therefore more favorable for the retrieval, while the uncertainty is expected to be higher for the day-time overpasses. AMSR-E has daily descending (01:30 equatorial local crossing time) and ascending (13:30 equatorial local crossing time) overpasses. The VOD retrievals from both night- and day-time overpasses were used in this study, with the emphasis on the night-time VOD. Hereafter VOD represent retrievals from night-time overpasses, except where specified otherwise. Optical satellite vegetation data were also used to characterize canopy dynamics, including LAI and EVI. LAI is defined as the one-sided green leaf area per unit ground area. The LAI product used is the latest version (Collection 6) of MODIS from Terra and Aqua combined (Yan et al., 2016a, Yan et al., 2016b). For EVI, the Multi-Angle Implementation of Atmospheric Correction (MAIAC, Collection 6) MODIS product was used. Advantages of the MAIAC data are that they received more sophisticated atmospheric correction, more accurate and less conservative cloud detection, improved sensor calibration, and sun-sensor geometry correction (Bi et al., 2016, Lyapustin et al., 2011a, Lyapustin et al., 2011b, Lyapustin et al., 2012). These data 
represent the state-of-the-art in accounting for aerosol and bidirectional reflectance distribution function (BRDF) effects, but some noise may still exist (Bi et al., 2016).

The hydrometeorological variables used here include (1) rainfall (P) from the Tropical Rainfall Measuring Mission (TRMM 3B43 v7) (Huffman et al., 2007), (2) photosynthetically active radiation (PAR) from the Clouds and Earth's Radiant Energy System (CERES, SYN1deg Ed3A) on Aqua and Terra combined (Wielicki et al., 1996), (3) terrestrial water storage (TWS) dynamics estimated by removing the signals of other geophysical processes from the gravity field measured from the Gravity Recovery and Climate Experiment (GRACE) (Landerer \& Swenson, 2012, Swenson \& Wahr, 2006) , (4) land surface temperature (LST) from the daytime overpass (1:30 PM) of the Atmospheric Infrared Sounder (AIRS) onboard Aqua (version 6). Aerosol optical depth (AOD) and cloud optical thickness (COT) from the Terra MODIS instrument (Platnick et al., 2015) were used to characterize atmospheric conditions. In addition, near surface air temperature $\left(\mathrm{T}_{\mathrm{a}}\right)$ and surface relative humidity $(\mathrm{RH})$ from both the daytime and nighttime overpasses (1:30 PM and 1:30 AM, respectively) of the Atmospheric Infrared Sounder (AIRS) (version 6) were used to calculate vapor pressure deficit (VPD, see the section below).

\subsection{Data pre-processing}

For a more direct comparison, data were resampled to a monthly and $0.10^{\circ}$ resolution by aggregation or bilinear interpolation from their original resolutions. To minimize the influence of non-forest vegetation dynamics, the Amazonian forests are defined here as the $0.10^{\circ}$ grid cells in which all four $0.05^{\circ}$ grid cells have the same evergreen broadleaf forest land cover type (Fig. 1a). The presence of large-scale open water affects microwave emissions (Liu et al., 
2013). Therefore, the grid cells alongside the Amazon River (obtained from Digital Chart of the World) were masked out before analyzing VOD. Figure 1b shows that average VOD values over forests are generally greater than 0.9 ; we considered that the signal in grid cells with VOD $<0.9$ was influenced by the presence of open water, hence these grid cells were excluded from the analysis.
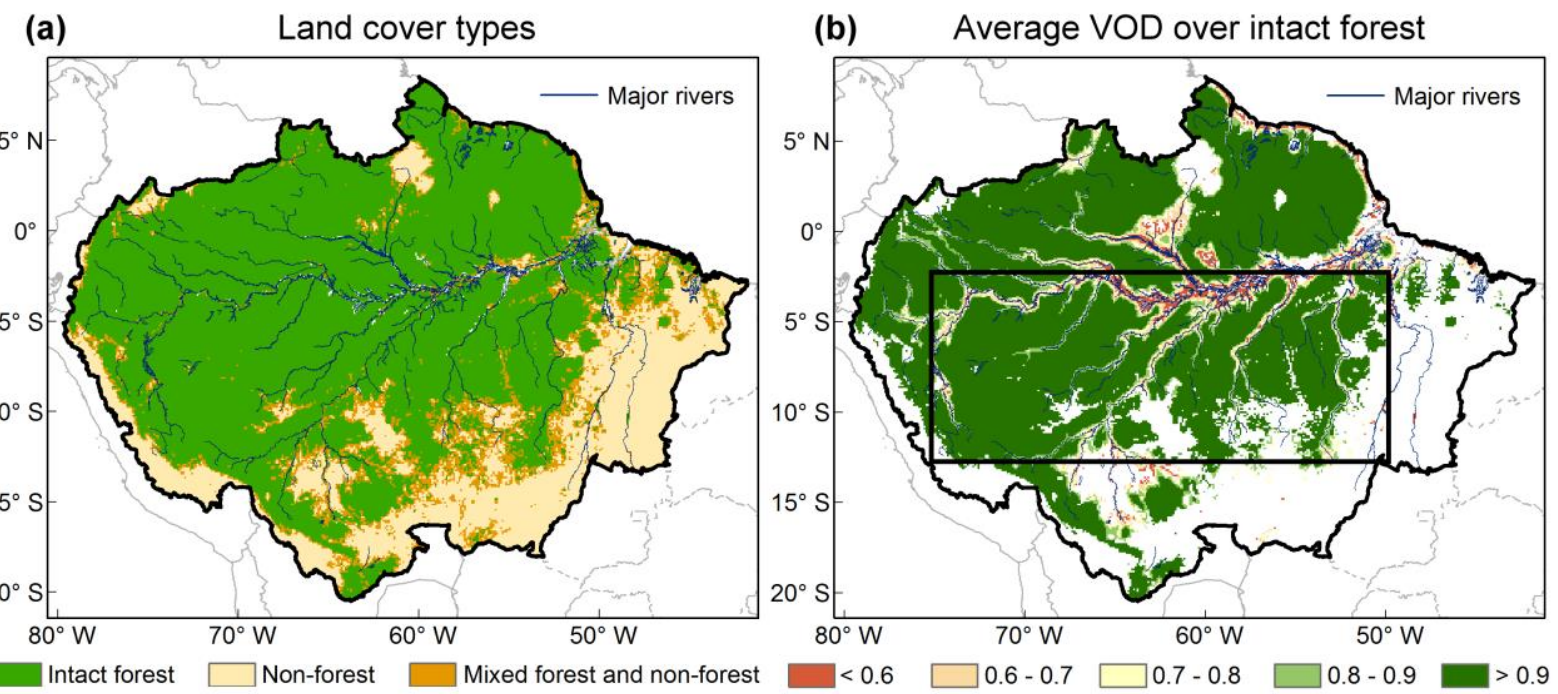

Fig 1. Spatial distribution of vegetation characteristics over the study area. (a) Land cover map (at $0.10^{\circ}$ spatial resolution) over Amazonia based on the $0.05^{\circ}$ MODIS IGBP classification product for 2010. 'Intact forest' means that all four $0.05^{\circ}$ grid cells in one $0.10^{\circ}$ grid cell are classified as forest. (b) The 'intact forest' in southern Amazonia $\left(2.5^{\circ} \mathrm{S}-12.5^{\circ} \mathrm{S}\right.$, $75^{\circ} \mathrm{W}-50^{\circ} \mathrm{W}$ as outlined) is the study area of this paper. The annual average VOD value at $0.10^{\circ}$ spatial resolution is displayed in the background. A brief comparison between the downscaled $\left(0.10^{\circ}\right)$ and original $\left(0.25^{\circ}\right)$ VOD data can be found in Fig. S1.

Atmospheric VPD is the difference between the theoretical pressure corresponding to saturated water vapor in the air $\left(e_{s}\right)$ and the actual pressure of water vapor in the air $\left(e_{a}\right)$; it is a measure of the evaporative demand of the atmosphere. Higher VPD reflects higher 
atmospheric moisture demand (Seager et al., 2015), and this can exacerbate physiological stress on vegetation under drought conditions, thereby reducing the photosynthesis (Jarvis 1976, Leuning 1995). The AIRS-based near surface air temperature $\left(T_{a}\right)$ represents observations around 1:30 PM and 1:30 AM, close to the maximum and minimum daily surface air temperature, respectively (i.e., $\mathrm{T}_{\mathrm{amAX}}$ and $\mathrm{T}_{\mathrm{aMIN}}$ in ${ }^{\circ} \mathrm{C}$ ). Accordingly, surface relative humidity $(\mathrm{RH}, \%)$ observations around 1:30 PM and 1:30 AM should be close to the minimum and maximum daily $\mathrm{RH}$ as well (i.e., $\mathrm{RH}_{\mathrm{MIN}}$ and $\mathrm{RH}_{\mathrm{MAX}}$ ). The VPD (in $\mathrm{kPa}$ ) is calculated as $e_{s-} e_{a}$, where:

$$
\begin{gathered}
\mathrm{e}_{\mathrm{s}}=\left[\mathrm{e}^{\mathrm{o}}\left(T_{a M A X}\right)+\mathrm{e}^{\mathrm{o}}\left(T_{a M I N}\right)\right] / 2 \\
\mathrm{e}^{\mathrm{o}}\left(T_{a M A X}\right)=0.6108 \times \exp \left[17.27 \times T_{a M A X} /\left(T_{a M A X}+237.3\right)\right] \\
\mathrm{e}^{\mathrm{o}}\left(T_{a M I N}\right)=0.6108 \times \exp \left[17.27 \times T_{a M I N} /\left(T_{a M I N}+237.3\right)\right] \\
\mathrm{e}_{\mathrm{a}}=\left[\mathrm{e}^{\mathrm{o}}\left(T_{a M A X}\right) \times\left(R H_{M I N} / 100\right)+\mathrm{e}^{\mathrm{o}}\left(T_{a M I N}\right) \times\left(R H_{M A X} / 100\right)\right] / 2
\end{gathered}
$$

\subsection{Analysis Methods}

First, we examined the temporal evolution of hydrometeorological conditions over southern Amazonia. The seasonal cycle of hydrometeorological variables over southern Amazonia in non-drought years was calculated by taking the average for 2003-2010 but excluding 2005 and 2010, for P, PAR, AOD, COT, TWS, LST and VPD. The anomalies of these variables during the extended dry season (May-October) in 2005 and 2010 were calculated with respect to the seasonal cycle of non-drought years. In addition, TWS represents a vertically-integrated sum of all water stores, including ground water, soil moisture, surface water and vegetation water. In non-drought years, when TWS reaches its minimum value during the dry season 
(referred to as $\mathrm{TWS}_{\mathrm{MIN}}$ ) (Guan et al., 2015), the sap flow and transpiration can remain at a high level, and there is little evidence for limitation of water use (Fisher et al., 2006, 2007). New leaf development and ecosystem photosynthesis increase during the dry season according to field observations (Wu et al., 2016). However, under drought conditions, soil moisture falls below the dry-season level for non-drought years, and sap flow is substantially reduced due to water limitation (Fisher et al., 2006, 2007). As such, we consider TWS ${ }_{\text {MIN }}$ as a threshold level: when TWS $>\mathrm{TWS}_{\mathrm{MIN}}$, sufficient water storage is assumed to be available for vegetation water demand, and when TWS $<\mathrm{TWS}_{\mathrm{MIN}}$, water deficit is assumed to occur. Likewise, $\mathrm{LST}_{\mathrm{MAX}}$ and $\mathrm{VPD}_{\mathrm{MAX}}$, which represent the maximum values of LST and VPD during the dry season of non-drought years, are also used as thresholds. The differences between the actual values in drought years and TWS $\mathrm{TIN}_{\mathrm{MIN}}, \mathrm{LST}_{\mathrm{MAX}}$ and $\mathrm{VPD}_{\mathrm{MAX}}$ were calculated for each grid cell during the onset and peak of droughts, to represent the temporal and spatial patterns of water deficit and heat stress.

For the vegetation indices (including VOD, EVI and LAI), standardized anomalies were calculated for a direct comparison with each other. For each grid cell, the anomaly represents the departure from the average for the same months within the reference period. These values were standardized by division over the corresponding standard deviation within the reference period. Here the reference period is 2003-2010 but excluding 2005 and 2010.

The non-parametric Wilcoxon signed rank test (Gibbons \& Chakraborti, 2011) was used to calculate the statistical significance of the anomalies. In this study, this test was first used to identify the grid cells over which the anomalies during droughts are statistically different from non-drought years at $p<0.05$. It was also used to determine whether the anomalies between 2005 and 2010 events were statistically different at $p<0.05$. 
264 Potential evapotranspiration is estimated to be around $100 \mathrm{~mm}$ per month over Amazonia with

265 relatively small variations between dry and wet seasons (Aragao et al., 2007, Guan et al.,

266 2015). It is normal for monthly rainfall to drop below $100 \mathrm{~mm}$ in the dry season of

267 non-drought years. Here we considered months which received rainfall below $100 \mathrm{~mm}$ and

268 also significantly $(p<0.05)$ below the average for non-drought years, which is expected to

269 cause soil moisture depletion. To delineate the severity of soil moisture stress, the total

270 number of months with rainfall below $100 \mathrm{~mm}$ and significantly $(p<0.05)$ below average was

271 calculated between May and October in 2005 and 2010 for each grid cell. 
Table 1. List of satellites datasets used in this study

\begin{tabular}{|c|c|c|c|}
\hline Dataset & $\begin{array}{l}\text { Sensor/ } \\
\text { Platform }\end{array}$ & $\begin{array}{l}\text { Original } \\
\text { spatial } \\
\text { resolution }\end{array}$ & Sources \\
\hline \multicolumn{4}{|r|}{ Vegetation characteristics } \\
\hline $\begin{array}{l}\text { Land Cover } \\
\text { Type }\end{array}$ & $\begin{array}{l}\text { MODIS/ } \\
\text { Terra and } \\
\text { Aqua }\end{array}$ & $0.05^{\circ}$ & $\begin{array}{l}\text { http://e4ft101.cr.usgs.gov/MOTA/MCD12C1.051/2010.01.01 } \\
\text { ('IGBP global vegetation classification scheme') }\end{array}$ \\
\hline $\begin{array}{l}\text { Vegetation } \\
\text { Optical Depth } \\
\text { (VOD) }\end{array}$ & $\begin{array}{l}\text { AMSR-E/ } \\
\text { Aqua }\end{array}$ & $\begin{array}{l}0.10^{\circ} \\
(\sim 10 \mathrm{~km})\end{array}$ & $\begin{array}{c}\text { Derived using the LPRM algorithm and the SFIM downscaling } \\
\text { technique, and VOD data available upon request }\end{array}$ \\
\hline $\begin{array}{l}\text { Leaf Area } \\
\text { Index (LAI) }\end{array}$ & $\begin{array}{l}\text { MODIS/ } \\
\text { Terra and } \\
\text { Aqua }\end{array}$ & $0.5 \mathrm{~km}$ & $\frac{\text { https://e4ft101.cr.usgs.gov/MOTA/MCD15A2H.006 }}{\text { MCD15A2H (V006) }}$ \\
\hline $\begin{array}{c}\text { Enhanced } \\
\text { Vegetation } \\
\text { Index (EVI) }\end{array}$ & $\begin{array}{l}\text { MODIS/ } \\
\text { Terra and } \\
\text { Aqua }\end{array}$ & $1 \mathrm{~km}$ & $\begin{array}{l}\mathrm{ftp}: / / \text { dataportal.nccs.nasa.gov/DataRelease/SouthAmerica/VI } \\
\text { (MAIAC Collection 6) }\end{array}$ \\
\hline \multicolumn{4}{|c|}{ Hydrometeorological variables } \\
\hline $\begin{array}{l}\text { Rainfall } \\
\text { (P) }\end{array}$ & $\begin{array}{c}\text { TRMM and } \\
\text { other } \\
\text { satellites }\end{array}$ & $0.25^{\circ}$ & $\begin{array}{c}\mathrm{ftp}: / / \text { disc2.nascom.nasa.gov/ftp/data/s4pa/TRMM_L3/TRMM_3B43 } \\
\text { (TRMM 3B43 v7) }\end{array}$ \\
\hline $\begin{array}{l}\text { Photosyntheti } \\
\text { cally Active } \\
\text { Radiation } \\
\text { (PAR) }\end{array}$ & $\begin{array}{l}\text { CERES/ } \\
\text { Terra and } \\
\text { Aqua }\end{array}$ & $1^{\circ}$ & $\begin{array}{l}\text { https://ceres-tool.larc.nasa.gov/ord-tool/jsp/SYN1degSelection.jsp } \\
\text { (PAR Surface Flux Direct' and PAR Surface Flux Diffuse') }\end{array}$ \\
\hline $\begin{array}{c}\text { Aerosol } \\
\text { Optical Depth } \\
\text { (AOD) }\end{array}$ & $\begin{array}{l}\text { MODIS/ } \\
\text { Terra }\end{array}$ & $1^{\circ}$ & $\begin{array}{c}\text { https://ladsweb.modaps.eosdis.nasa.gov/archive/allData/6/MOD08_M3 } \\
\text { ('Aerosol_Optical_Depth_Land_Ocean_Mean_Mean') }\end{array}$ \\
\hline $\begin{array}{l}\text { Cloud Optical } \\
\text { Thickness } \\
\text { (COT) }\end{array}$ & $\begin{array}{l}\text { MODIS/ } \\
\text { Terra }\end{array}$ & $1^{\circ}$ & $\begin{array}{c}\text { https://ladsweb.modaps.eosdis.nasa.gov/archive/allData/6/MOD08_M3 } \\
\text { ( 'Cloud_Optical_Thickness_Combined_Mean_Mean') }\end{array}$ \\
\hline $\begin{array}{l}\text { Terrestrial } \\
\text { Water } \\
\text { Storage } \\
\text { (TWS) }\end{array}$ & GRACE & $1^{\circ}$ & $\begin{array}{c}\mathrm{ftp}: / / \text { podaac-ftp.jpl.nasa.gov/allData/tellus/L3/land_mass/RL05 } \\
\text { (RL05.DSTvSCS1401, simple arithmetic mean of JPL, CSR and GFZ } \\
\text { fields used) }\end{array}$ \\
\hline $\begin{array}{l}\text { Surface Skin } \\
\text { Temperature } \\
\quad(\text { LST) }\end{array}$ & $\begin{array}{c}\text { AIRS/ } \\
\text { Aqua }\end{array}$ & $1^{\circ}$ & $\begin{array}{l}\text { ftp://acdisc.sci.gsfc.nasa.gov/data/s4pa/Aqua_AIRS_Level3 } \\
\text { ('SurfSkinTemp_A') } \\
\text { 'A' representing ascending overpasses with equatorial crossing time } \\
\text { 1:30PM }\end{array}$ \\
\hline $\begin{array}{l}\text { Surface Air } \\
\text { Temperature } \\
\quad\left(\mathrm{T}_{\mathrm{a}}\right)\end{array}$ & $\begin{array}{l}\text { AIRS/ } \\
\text { Aqua }\end{array}$ & $1^{\circ}$ & $\begin{array}{l}\mathrm{ftp}: / / \text { acdisc.sci.gsfc.nasa.gov/data/s4pa/Aqua_AIRS_Level3 } \\
\text { ('SurfAirTemp_A' and 'SurfAirTemp_D') } \\
\text { 'D' representing ascending overpasses with equatorial crossing time } \\
\text { 1:30AM }\end{array}$ \\
\hline $\begin{array}{l}\text { Surface } \\
\text { Relative } \\
\text { Humidity } \\
\text { (RH) }\end{array}$ & $\begin{array}{l}\text { AIRS/ } \\
\text { Aqua }\end{array}$ & $1^{\circ}$ & $\begin{array}{l}\mathrm{ftp}: / / \text { acdisc.sci.gsfc.nasa.gov/data/s4pa/Aqua_AIRS_Level3 } \\
\text { ('RelHumSurf_A' and ' RelHumSurf_D') }\end{array}$ \\
\hline
\end{tabular}




\subsection{Hydrometeorological anomalies in 2005 and 2010 droughts}

Over southern Amazonia $\left(2.5-12.5^{\circ} \mathrm{S}, 50-75^{\circ} \mathrm{W}\right.$, Fig. $\left.1 \mathrm{~b}\right)$, there is a strong seasonal cycle in rainfall $(\mathrm{P})$ and photosynthetically active radiation (PAR) (Fig. 2a). The average rainfall from May through October is much lower than other months, with July and August being the driest. Radiation reaches its lowest value in May, starts increasing from June and stays at a high level over July - October. The seasonal cycle of clouds (COT) is similar to rainfall, with low values in the dry season (Fig. 2b). In contrast, the aerosol concentration (AOD) is much higher during the dry season (August-October) mainly due to large-scale biomass burning activities (Artaxo et al., 2013).

Figure 2c shows the seasonal cycle of TWS, LST and VPD over southern Amazonia. The TWS reaches its peak value in April and starts to decline from May onwards. After hitting its lowest value in October (referred to as $\mathrm{TWS}_{\mathrm{MIN}}$ ), it increases again with increased rainfall and decreased radiation. Both VPD and LST increase at the start of the dry season and reach the highest values in August and October, respectively, which are referred to as $\mathrm{VPD}_{\mathrm{MAX}}$ and $\mathrm{LST}_{\mathrm{MAX}}$. 
Seasonal cycle over southern Amazon derived from non-drought years

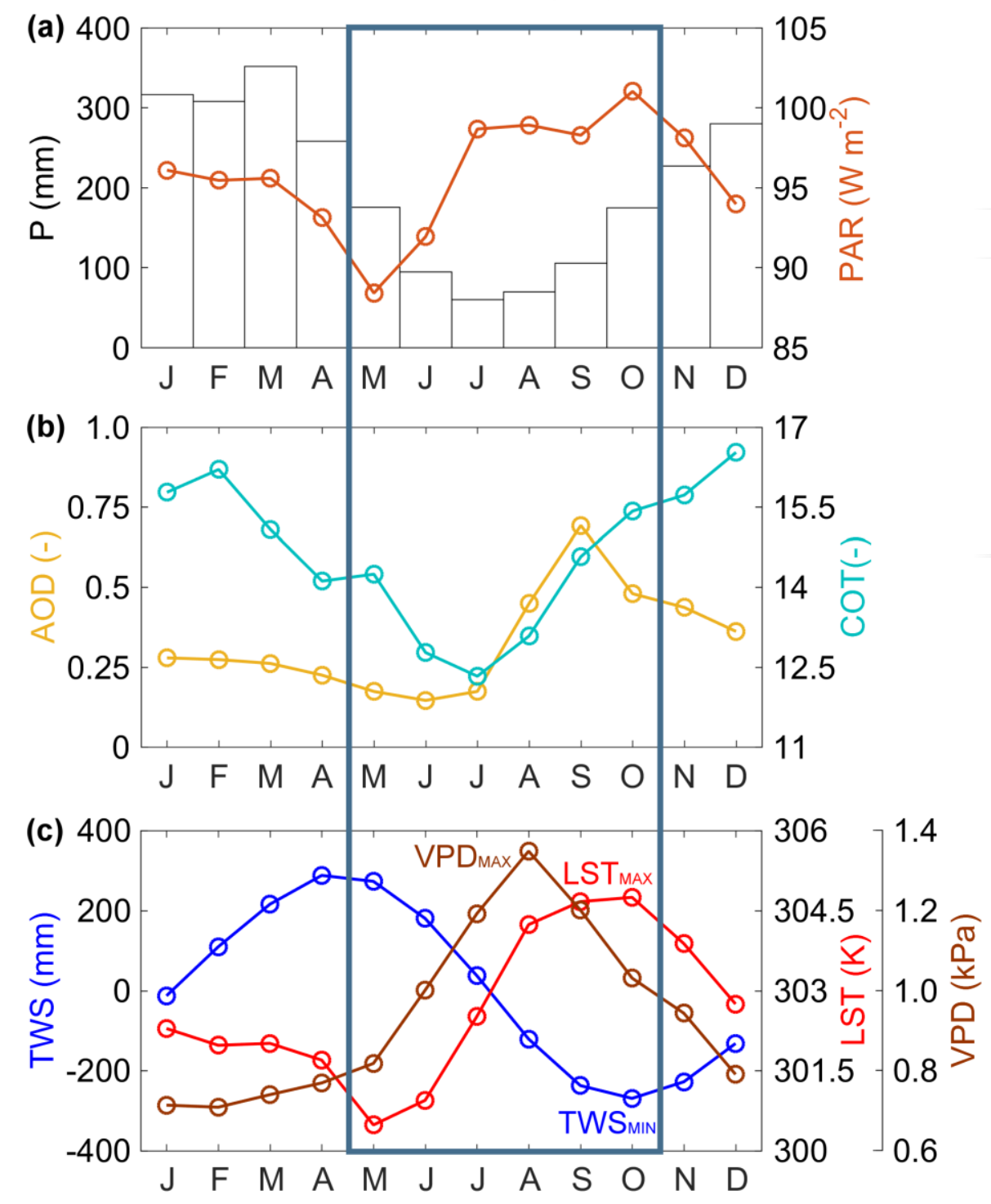

Fig 2. Hydrometeorological dynamics over southern Amazonia during non-drought years.

292 Seasonal cycles of rainfall $\left(\mathrm{P}, \mathrm{mm} \mathrm{month}^{-1}\right.$ ), photosynthetically active radiation (PAR, W $293 \mathrm{~m}^{-2}$ ), aerosol optical depth (AOD), cloud optical thickness (COT), terrestrial water storage 294 (TWS, mm), land surface temperature (LST, K) and vapor pressure deficit (VPD, kPa) over 295 the intact forest region in southern Amazonia during non-drought years (i.e., averaged over 296 2003-2010, excluding 2005 and 2010). The anomalies in 2005 and 2010 will be examined in 297 detail over the extended dry season (May-October) that is outlined by the blue box. 
Given the difference in the timing of the rainfall anomalies between 2005 and 2010, we separately considered hydrometeorological conditions during the onset of droughts in the wet-to-dry season (May-July) and during the peak of droughts in the dry season (August-October) (Fig. 3). Strong rainfall anomalies were observed in the wet-to-dry season in 2005, whereas the rainfall in 2010 was only slightly below average (Fig. 3a). By contrast, rainfall deficits were observed in the dry season in both years, but much stronger in 2010 . In both years, radiation was generally above average during the wet-to-dry season and below average during the dry season (Fig. 3b), but the magnitudes of anomalies differed between these two years. Radiation was above average in May and June of both years corresponding to below-average cloudiness. While radiation was still above average in July 2005, increased cloud cover reduced radiation to below average in July 2010. Conversely, greater aerosol loads and cloudiness in August-September 2005 caused a stronger negative radiation anomaly when compared to 2010 (Fig. 3c, d). Negative rainfall and high-level radiation caused strong anomalies in TWS, LST and VPD (Fig. 3e, f, g). These variables exceeded their ranges of non-drought years, with stronger magnitudes in 2010.

Spatially, significant negative anomalies in rainfall were primarily observed over southwestern Amazonia during both wet-to-dry and dry seasons in 2005, and over entire southern Amazonia during the dry season in 2010 (Fig. 4a, b, c, d). Spatial patterns of positive radiation anomalies agreed well with negative rainfall anomalies during the wet-to-dry season in both years (Fig. 4e, f). The overall positive radiation anomalies can be attributed to strong positive anomalies in direct PAR and weak negative anomalies in diffuse PAR (Fig. S2) as a consequence of reduced cloud cover and/or aerosol loads. On the other hand, strong negative 
321 events, with greater magnitudes and spatial coverage in 2005 (Fig. 4g, h).
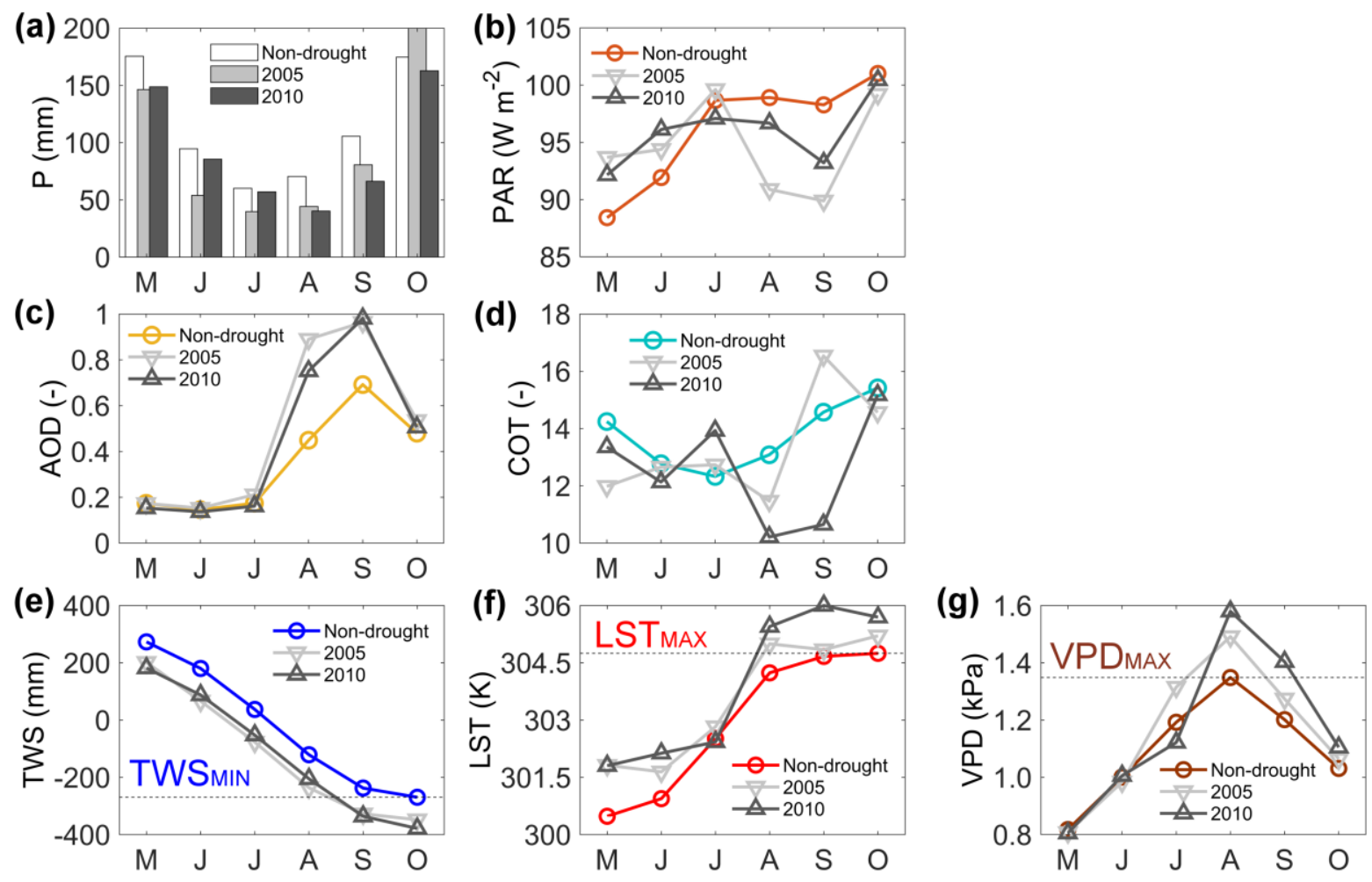

Fig 3. Hydrometeorological anomalies over southern Amazonia in the 2005 and 2010

324 droughts. Time series of monthly average (a) rainfall (P), (b) photosynthetically active

325 radiation (PAR), (c) aerosol optical depth (AOD), (d) cloud optical thickness (COT), (e)

terrestrial water storage (TWS), (f) land surface temperature (LST) and (g) vapor pressure

327 deficit (VPD) over southern Amazonia from May through October in 2005 and 2010 in comparison with non-drought years, respectively. 


\section{Anomaly in $\mathrm{P}$}
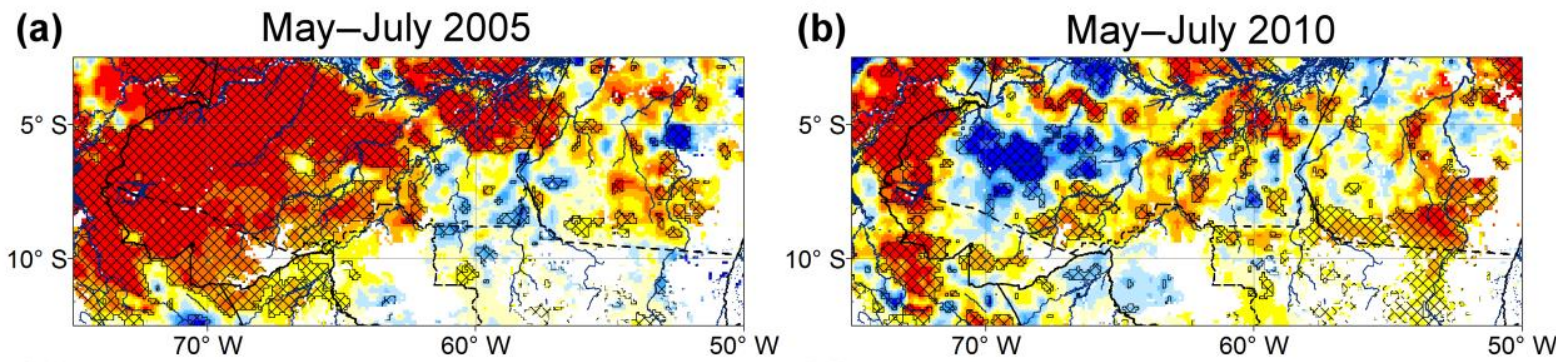

(c) August-September 2005

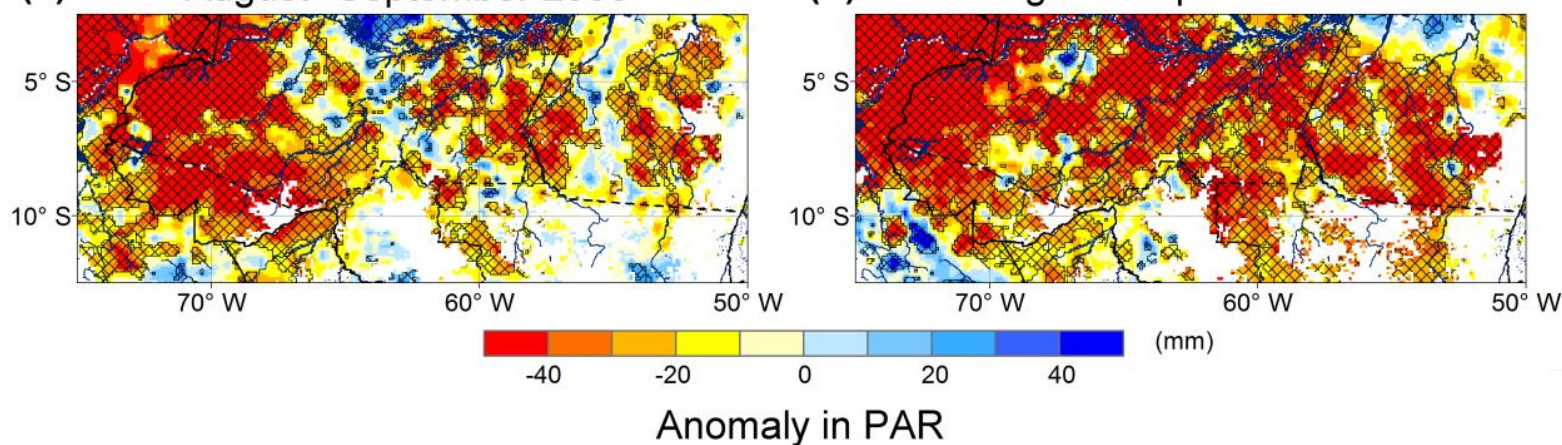

(e) May-July 2005

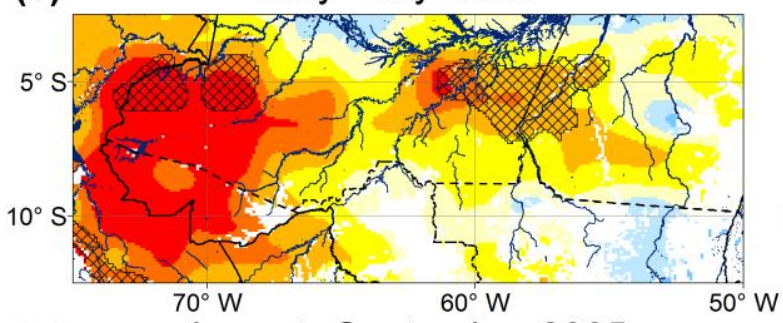

(g) August-September 2005

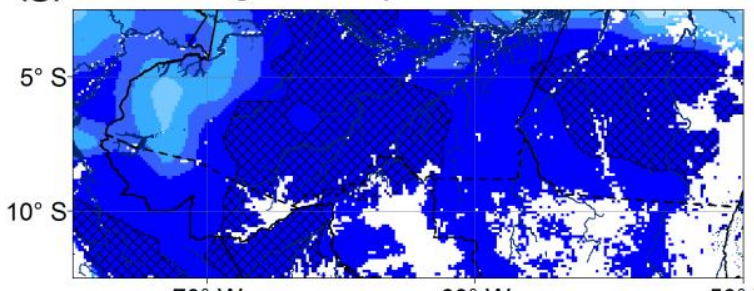

$70^{\circ} \mathrm{W}$

$50^{\circ} \mathrm{W}$ (f)

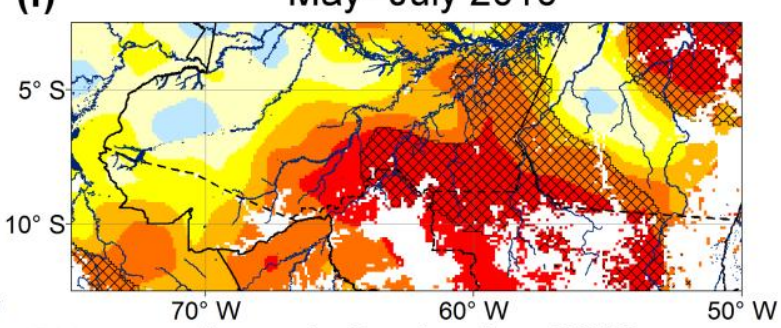

(h) August-September 2010

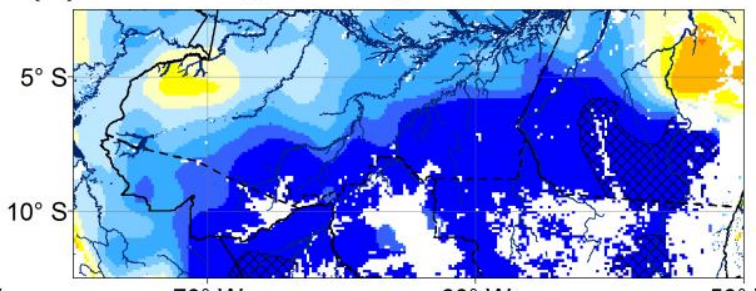

$\left(\mathrm{W} \mathrm{m}^{-2}\right)$

$70^{\circ} \mathrm{W}$

$0^{\circ} \mathrm{W}$

$50^{\circ} \mathrm{W}$

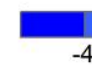

Fig 4. Anomalies in rainfall $(\mathrm{P}, \mathrm{mm})$ and photosynthetically active radiation $\left(\mathrm{PAR}, \mathrm{W} \mathrm{m}^{-2}\right.$ ) for

331 the onset of drought during the wet-to-dry season (May-July) and the peak of drought during

332 the dry season (August-September) of 2005 and 2010. Anomalies represent the departure

333 from the average of non-drought years. The areas with statistically significant anomalies

based on non-parametric Wilcoxon signed rank test $(p<0.05)$ are hatched. 


\subsection{Vegetation response during the onset of droughts}

Figure 5 shows the standardized anomalies in VOD, LAI and EVI during the onset of droughts in the wet-to-dry season (May-July) of 2005 and 2010. As the concentration of atmospheric aerosols was low in these three months (Fig. 3c), the optical vegetation information (i.e., LAI and EVI) can be expected to be reliable. These three vegetation variables represent different properties of the forest canopy (i.e., VOD for canopy water content, LAI for leaf area and EVI for canopy greenness), but all show large-scale positive anomalies during the onset of both droughts. Table 2 lists the percentage of southern Amazonia with VOD, LAI and EVI anomalies of different magnitudes during the onset of droughts in 2005 and 2010. The median anomalies in VOD, LAI and EVI were all positive in both years, but their magnitudes differed significantly $(p<0.05)$ and were stronger overall in 2005 than in 2010.

These positive anomalies in VOD, LAI and EVI in both years, as well as their differences, seem related to the hydrometeorological conditions. In 2005, strong rainfall deficits during the onset of droughts were associated with above-average radiation (Fig. 3a, b), resulting in a positive anomaly in both VPD and canopy temperature, and a negative anomaly in terrestrial water storage (Fig. 3e, f, g). However, they did not exceed the VPD MAX, LST $_{\text {MAX }}$ and TWS $_{\text {MIN }}$ observed during non-drought years (Fig. 6), suggesting (1) that there was a higher atmospheric moisture demand but still sufficient soil water supply remained available for photosynthesis and growth and (2) that heat and water stress in the top of the canopy were within the typical dry season ranges. In addition, the diurnal VOD signals between drought and non-drought years were compared following the approach in Konings and Gentine (2017). 
The results suggest that there is little evidence for stomatal closure during the onset of droughts over southern Amazonia in May-July 2005 and 2010 compared to the non-drought years (Fig. S3).

Below-average rainfall and above-average radiation during the onset of droughts appears to be equivalent to an early arrival of normal dry season, during which enhanced leaf development and ecosystem photosynthesis in Amazonia are observed according to field observations (Wu et al., 2016). The strong positive anomalies in VOD, LAI, and EVI, occurred during these three months, are therefore consistent with the expected increase in leaf production under sufficient soil water supply (Brando et al., 2010, Nepstad et al., 1994). The enhanced canopy growth in May-July 2005 was much stronger than 2010, which is very likely due to the greater positive anomalies in radiation in 2005 (as shown Fig. 3 and 4). Furthermore, the distribution of standardized anomalies in VOD during the onset of droughts was compared with that at the end of 2004 and 2009. The results suggest that the positive anomalies in VOD during the onset of both droughts are likely caused by the unusual hydrometeorological conditions in the drought years, and not a delayed response to the previous year (Fig. S4). 

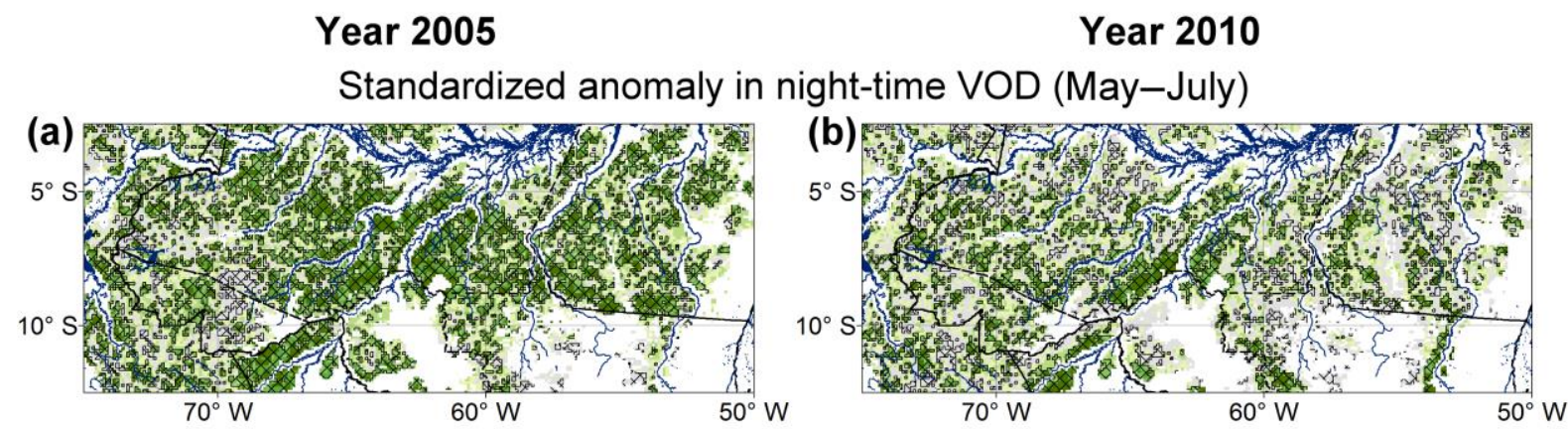

Standardized anomaly in LAI (May-July)
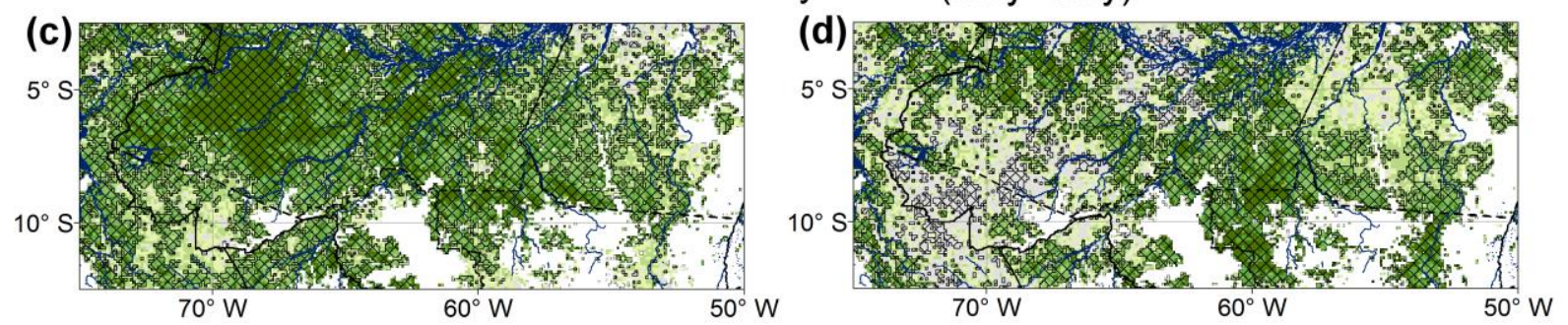

Standardized anomaly in EVI (May-July)
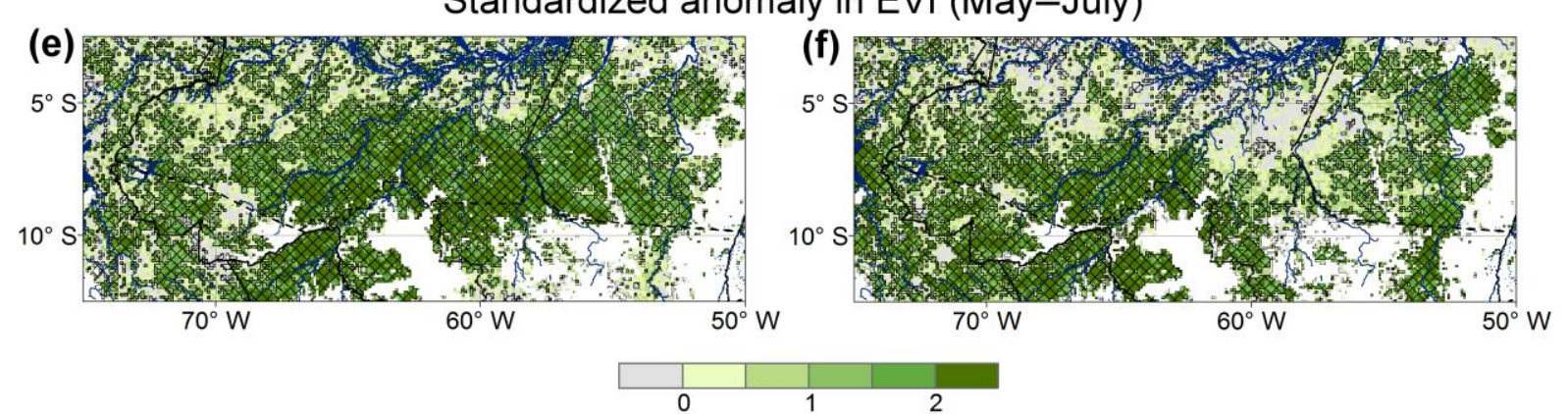

375 Fig 5. Standardized anomalies in vegetation indicators during the onset of droughts

376 (May-July) in 2005 and 2010. Units represent the number of standard deviations as a

377 departure from the average of non-drought years in ( $a$ and $b$ ) night-time vegetation optical

378 depth (VOD), (c and d) leaf area index (LAI), and (e and f) enhanced vegetation index (EVI).

379 Areas with statistically significant anomalies based on the non-parametric Wilcoxon signed rank test $(\mathrm{p}<0.05)$ are hatched. 

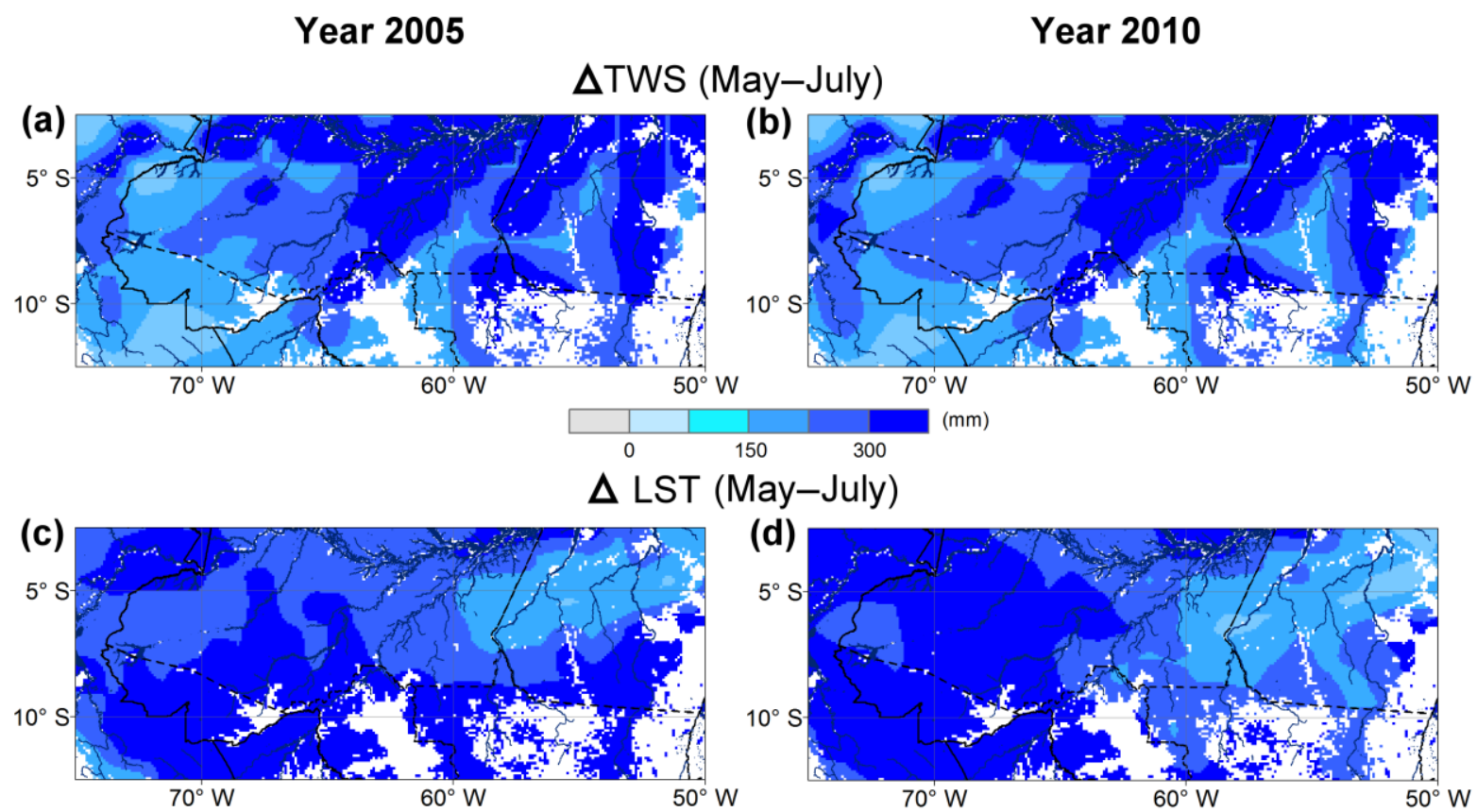

$$
\Delta \text { VPD (May-July) }^{-3}
$$

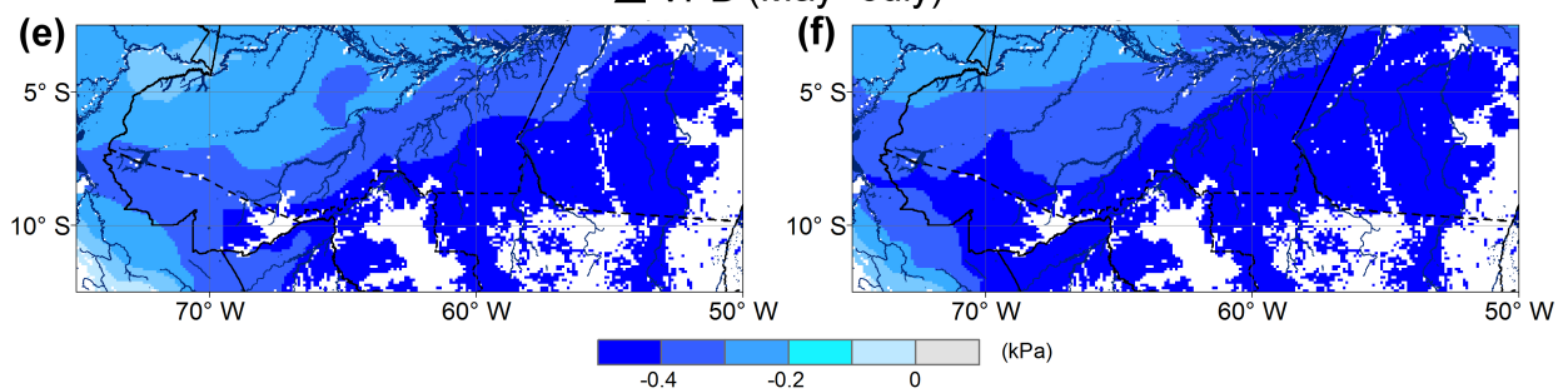

Fig 6. (a and b) Mean TWS over May-July minus TWS $_{\text {MIN }}$ during the non-drought years for non-drought years $(\triangle \mathrm{VPD})$. 
Table 2. Percentage of southern Amazonia corresponding to different anomaly magnitudes for

VOD, LAI and EVI during May - July in 2005 and 2010.

\begin{tabular}{|c|c|c|c|c|c|c|c|c|}
\hline $\begin{array}{c}\text { May } \\
- \\
\text { July }\end{array}$ & $\begin{array}{l}<-2 \\
\mathrm{SD}^{1}\end{array}$ & $\begin{array}{c}-2 \text { to }-1 \\
\text { SD }\end{array}$ & $\begin{array}{c}-1 \text { to } 1 \\
\text { SD }\end{array}$ & $\begin{array}{c}1 \text { to } 2 \\
\text { SD }\end{array}$ & $\begin{array}{l}>2 \\
\mathrm{SD}\end{array}$ & Total & $\begin{array}{c}\text { Median } \\
\text { anomaly } \\
\pm \mathrm{SD}\end{array}$ & $\begin{array}{c}\text { Significantly } \\
\text { different } \\
(\mathrm{p}<0.05)\end{array}$ \\
\hline \multicolumn{9}{|c|}{ VOD } \\
\hline 2005 & $0.9 \%$ & $3.9 \%$ & $58.2 \%$ & $25.6 \%$ & $11.3 \%$ & $100 \%$ & $\begin{array}{c}0.77 \\
\pm 1.09\end{array}$ & \multirow{2}{*}{ Yes } \\
\hline 2010 & $2.6 \%$ & $9.1 \%$ & $67.8 \%$ & $14.6 \%$ & $5.9 \%$ & $100 \%$ & $\begin{array}{c}0.21 \\
\pm 1.09\end{array}$ & \\
\hline \multicolumn{9}{|c|}{ LAI } \\
\hline 2005 & $0.1 \%$ & $0.3 \%$ & $29.3 \%$ & $44.1 \%$ & $26.3 \%$ & $100 \%$ & $\begin{array}{c}1.39 \\
\pm 1.12\end{array}$ & \multirow{2}{*}{ Yes } \\
\hline 2010 & $0.9 \%$ & $3.9 \%$ & $51.2 \%$ & $31.8 \%$ & $12.1 \%$ & $100 \%$ & $\begin{array}{c}0.86 \\
\pm 1.15\end{array}$ & \\
\hline \multicolumn{9}{|c|}{ EVI } \\
\hline 2005 & $0.2 \%$ & $0.9 \%$ & $32.8 \%$ & $34.9 \%$ & $31.1 \%$ & $100 \%$ & $\begin{array}{c}1.43 \\
\pm 1.32\end{array}$ & \multirow{2}{*}{ Yes } \\
\hline 2010 & $0.4 \%$ & $1.4 \%$ & $40.1 \%$ & $32.1 \%$ & $25.9 \%$ & $100 \%$ & $\begin{array}{c}1.21 \\
\pm 1.41\end{array}$ & \\
\hline
\end{tabular}

${ }^{1} \mathrm{SD}$ : standard deviation

\subsection{Vegetation response during the peak of droughts}

394

395

Due to the presence of extremely high atmospheric aerosols during the peak of 2005 and 2010 droughts (Fig. 3c), the accuracy of optical observations is expected to be adversely affected. Therefore we excluded LAI and EVI from this section and only focused on VOD. Anomalies in canopy water content (represented by VOD) during the peak of droughts (August-October) of both drought years are presented in Fig. 7. Significantly negative anomalies in VOD were found primarily over southwestern Amazonia in 2005 (Fig. 7a). The spatial pattern of VOD anomalies agrees well with the findings of Saatchi et al. (2012) in which the radar backscatter from QSCAT was used to characterize the anomalies in canopy structure and moisture in 2005. 
402

403

404

405

406

407

408

409

410

411

412

413

414

415

In the event of 2010, significantly negative anomalies in VOD were more widespread, covering the central and eastern parts of southern Amazonia (Fig. 7b). Similar spatial patterns of negative VOD anomalies were also found in the day-time retrievals despite higher uncertainties (Fig. S5).

Table 3 summarizes the fractions of southern Amazonia (\%) for different magnitudes of VOD anomalies during the peak of droughts (August-October) of both events. When all grid cells over southern Amazonia are considered, $14.3 \%$ and $14.8 \%$ of the area showed anomalies more than two standard deviations below the average for non-drought years (i.e., <-2 SD) in 2005 and 2010, respectively. The median $( \pm$ SD) standardized anomaly is $-0.51( \pm 2.07)$ and $-0.56( \pm 1.48)$, respectively for 2005 and 2010; their difference is not statistically significant (i.e., $p>0.05$ ) based on non-parametric Wilcoxon signed rank test. When only taking account the grid cells with strong negative anomalies (i.e., less than two standard deviations), the mean standardized anomaly is -2.78 and -2.65 for 2005 and 2010, respectively; this difference is statistically significant $(p<0.05)$. 
Year 2005

Year 2010

Standardized anomaly in night-time VOD (August-October)

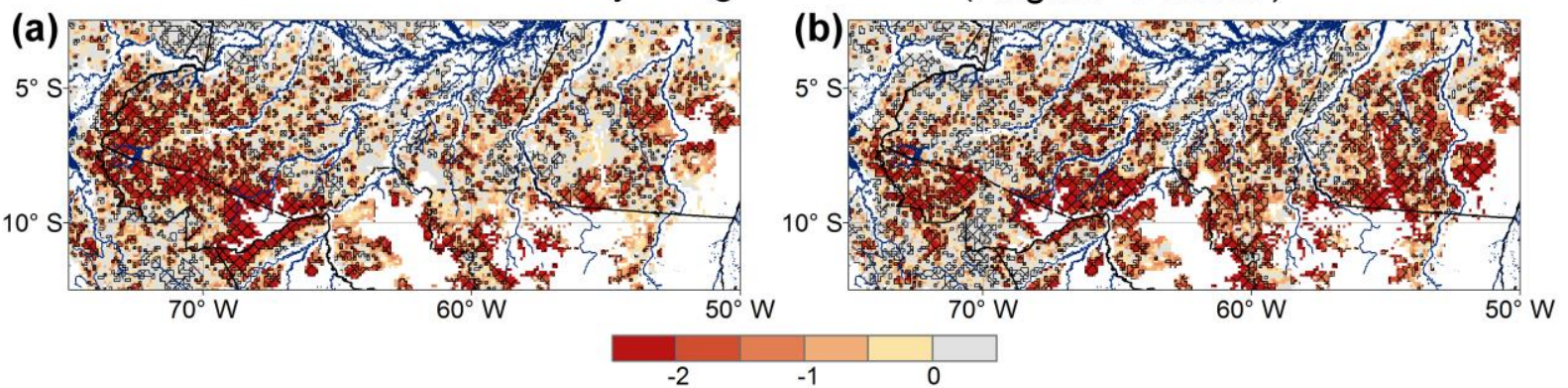

Fig 7. Standardized anomalies in night-time VOD during the peak of droughts

419 (August-October) in 2005 and 2010. Units represent the number of standard deviations as a

departure from the average of non-drought years. Areas with statistically significant

421 anomalies based on non-parametric Wilcoxon signed rank test $(p<0.05)$ are hatched.

Table 3. Percentage of southern Amazonia corresponding to different anomaly magnitudes for

VOD during August-October in 2005 and 2010.

\begin{tabular}{|c|c|c|c|c|c|c|c|c|}
\hline \multicolumn{9}{|c|}{ For all grid cells over southern Amazonia } \\
\hline $\begin{array}{c}\text { August } \\
- \\
\text { October }\end{array}$ & $\begin{array}{l}<-2 \\
\mathrm{SD}\end{array}$ & $\begin{array}{c}-2 \text { to }-1 \\
\text { SD }\end{array}$ & $\begin{array}{c}-1 \text { to } 1 \\
\text { SD }\end{array}$ & $\begin{array}{l}1 \text { to } 2 \\
\text { SD }\end{array}$ & $\begin{array}{l}>2 \\
\text { SD }\end{array}$ & Total & $\begin{array}{c}\text { Median } \\
\text { anomaly } \\
\pm \text { SD }\end{array}$ & $\begin{array}{c}\text { Significantly } \\
\text { different } \\
(\mathrm{p}<0.05)\end{array}$ \\
\hline 2005 & $14.3 \%$ & $19.7 \%$ & $56.3 \%$ & $6.9 \%$ & $2.8 \%$ & $100 \%$ & $\begin{array}{c}-0.51 \\
\pm 2.07\end{array}$ & \multirow{2}{*}{ No } \\
\hline 2010 & $14.8 \%$ & $21.6 \%$ & $51.0 \%$ & $8.7 \%$ & $3.9 \%$ & $100 \%$ & $\begin{array}{r}-0.56 \\
\pm 1.55\end{array}$ & \\
\hline \multicolumn{9}{|c|}{ For the grid cells with "<-2 SD" anomaly } \\
\hline $\begin{array}{c}\text { August } \\
- \\
\text { October }\end{array}$ & $\begin{array}{l}<-6 \\
\mathrm{SD}\end{array}$ & $\begin{array}{c}-6 \text { to }-5 \\
\text { SD }\end{array}$ & $\begin{array}{c}-5 \text { to }-4 \\
\text { SD }\end{array}$ & $\begin{array}{c}-4 \text { to }-3 \\
\text { SD }\end{array}$ & $\begin{array}{c}-3 \text { to }-2 \\
\text { SD }\end{array}$ & Total & $\begin{array}{l}\text { Median } \\
\text { anomaly } \\
\pm \mathrm{SD}\end{array}$ & $\begin{array}{c}\text { Significantly } \\
\text { different } \\
(\mathrm{p}<0.05)\end{array}$ \\
\hline 2005 & $0.7 \%$ & $0.6 \%$ & $1.3 \%$ & $3.3 \%$ & $8.4 \%$ & $14.3 \%$ & $\begin{array}{c}-2.78 \\
\pm 1.36\end{array}$ & \multirow{2}{*}{ Yes } \\
\hline 2010 & $0.3 \%$ & $0.4 \%$ & $1.1 \%$ & $3.2 \%$ & $9.8 \%$ & $14.8 \%$ & $\begin{array}{c}-2.65 \\
\pm 1.02\end{array}$ & \\
\hline
\end{tabular}


425 Meanwhile, terrestrial water storage was well below TWS $_{\text {MIN }}$, and canopy temperatures and vapor pressure deficit were above $\mathrm{LST}_{\mathrm{MAX}}$ and $\mathrm{VPD}_{\mathrm{MAX}}$, respectively (Fig. 8a-f). Similar

427 spatiotemporal patterns in VPD were found when using ERA-interim data (see Fig. S6),

428 further supporting the AIRS-based VPD estimates. These strong anomalies were observed

429 over large parts of southwestern Amazonia in 2005 and over the central and eastern parts of

430 southern Amazonia in 2010. While the magnitude and spatial coverage of negative TWS

431 anomalies were greater in 2010 (Fig. 8a, b), the soil moisture stress based on the magnitude

432 and duration of rainfall deficit was much stronger in 2005 (Fig. 8g, h). The spatial agreements

433 between negative VOD anomalies and hydrometeorological anomalies strongly suggest that

434 below-average canopy water content resulted from the combined effects of severe water stress

435 and heat stress, which agrees with the findings of Toomey et al. (2011). They found that

436 jointly considering heat and moisture stress can better explain the reduction of aboveground

437 living biomass observed by the ground RAINFOR network. 


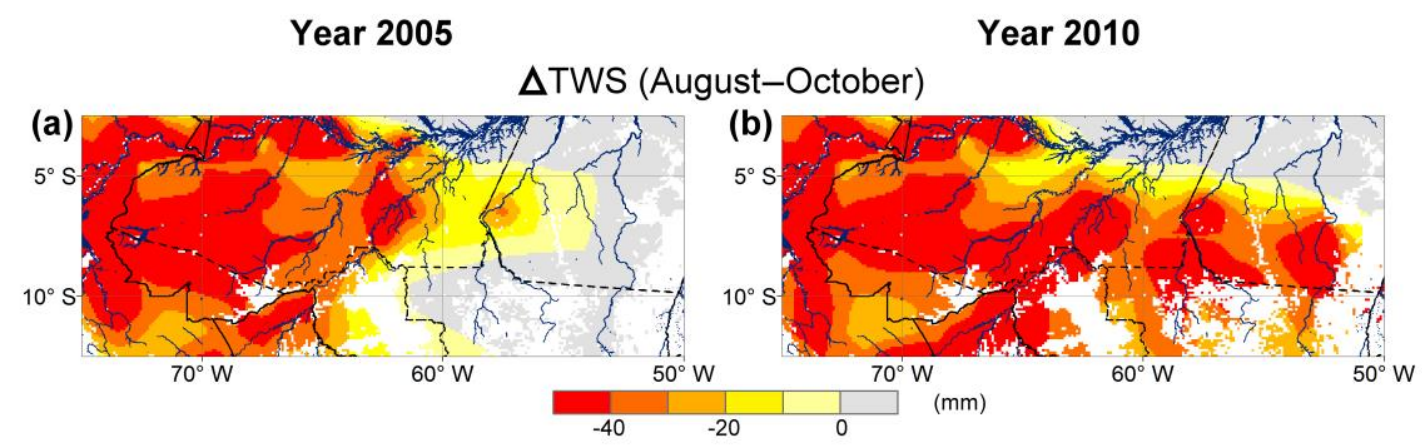

$\Delta$ LST (August-October)

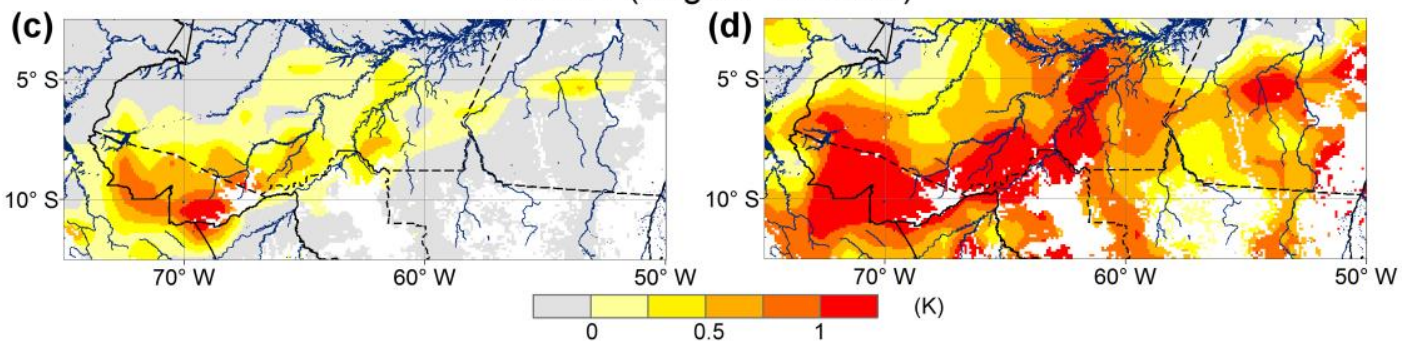

$\Delta$ VPD (August-September)

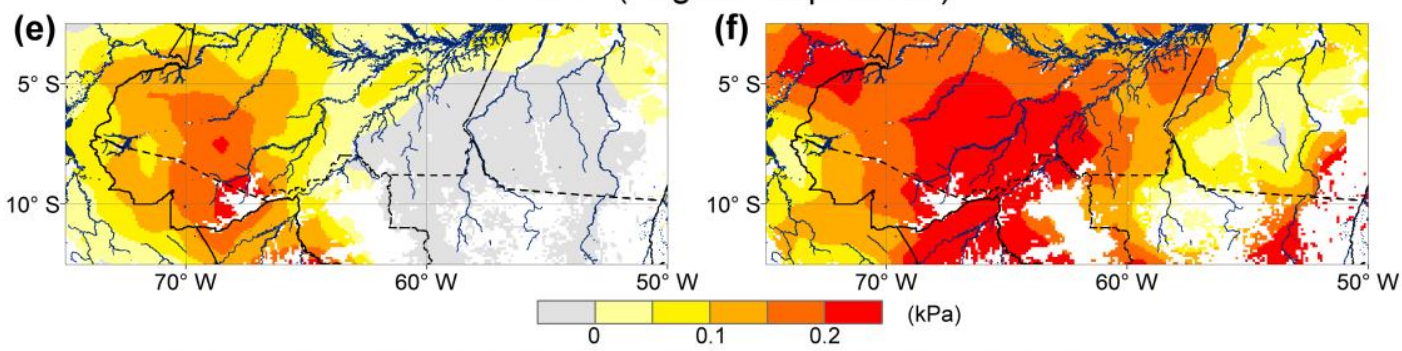

\# of months with rainfall below $100 \mathrm{~mm}$ and significantly below average

May-October 2005

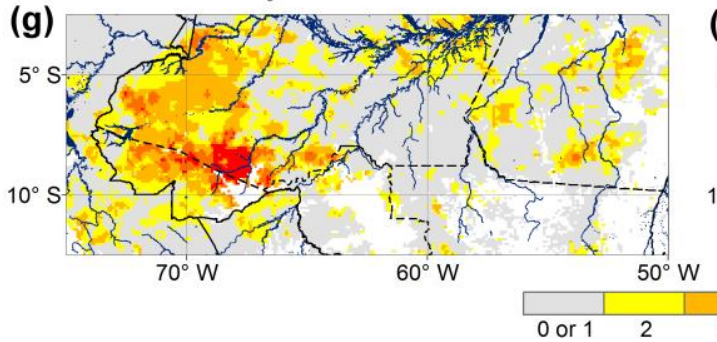

May-October 2010

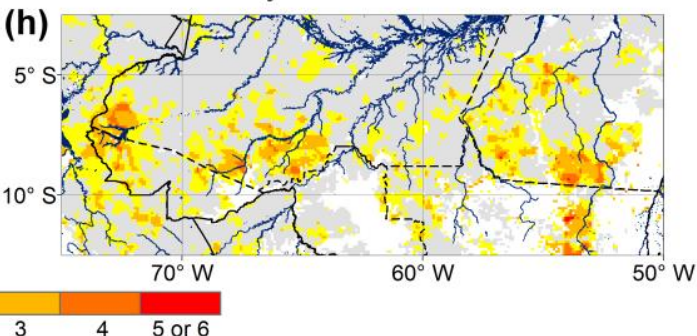

439 Fig 8. (a and b) Mean TWS over August-October minus $\mathrm{TWS}_{\mathrm{MIN}}$ during the non-drought

$V_{P D} D_{M A X}$ during the non-drought years $(\triangle \mathrm{VPD})$. $(\mathrm{g}$ and $\mathrm{h})$ Total number of months with

monthly rainfall below $100 \mathrm{~mm}$ and significantly below average of non-drought years, 
During the 2005 and 2010 droughts, significantly negative anomalies in canopy water content, represented by VOD, were found primarily over southwestern Amazonia in 2005, while negative VOD anomalies were located in central and eastern parts of southern Amazonia in 2010. The total areas with negative VOD anomalies greater than two standard deviations were similar during the two droughts (i.e., $14.3 \%$ and $14.8 \%$, respectively). When only considering the grid cells with more than two standard deviations below the average, the 2005 drought showed a significantly more severe decline in canopy water content. This qualitatively agrees with field observations that suggest the reduction in carbon uptake was stronger in 2005 than 2010 (Feldpausch et al., 2016). Interestingly, Feldpausch et al. (2016) also found that reduced carbon uptake was primarily caused by increased tree mortality in 2005 , but by a combination of high mortality and slow tree growth in 2010. During both droughts, reduced carbon uptake (i.e., the combined effect of tree mortality and slow tree growth) was related to the strength of moisture deficit. But in 2010, there was no clear relationship between increased tree mortality and water deficit anomaly (Feldpausch et al., 2016).

Our findings help to scale up and explain these field observations. Firstly, the duration of soil moisture depletion (i.e., monthly rainfall below $100 \mathrm{~mm}$ and significantly below average of southwestern Amazonia experienced three or more months of soil moisture depletion in 2005, whereas only a few small areas did in 2010. Moreover, enhanced canopy growth during the onset of 2005 drought in the wet-to-dry season (May-July) would accelerate soil moisture depletion. Significant negative VOD anomalies were found in these regions with three or 
more months of soil moisture depletion in both droughts, regardless of the magnitude of temperature and VPD anomalies. This suggests that soil moisture stress in these regions may have exceeded the tolerance limit of the rainforest, resulting in declines in canopy water content and presumably increased tree mortality.

Secondly, from the onset to the peak of drought in 2010, most of southern Amazonia experienced only one month of soil moisture depletion (Fig. 8h), mainly in August and September. This indicates that a soil water deficit likely occurred in the shallow soil, rather than at greater depth. Then high canopy temperature and atmospheric moisture demand during August-September 2010 appeared to have resulted primarily from a concurrent strong rainfall deficit and high radiation flux, rather than insufficient soil water supply alone. The high temperatures and atmospheric moisture demand can cause near-instantaneous declines in carbon assimilation and slow tree growth (Doughty \& Goulden, 2008, Toomey et al., 2011), but may not have been severe enough to cause large-scale mortality.

The above findings are supported by the two partial throughfall exclusion experiments (TFEs) over eastern Amazonia (Brando et al., 2008, da Costa et al., 2010, Rowland et al., 2015), in which a fraction of the throughfall was prevented from infiltrating into the soil. In one experiment, throughfall was reduced continuously for several years, while in the other experiment only wet season throughfall was reduced. Soil moisture, tree mortality and wood volume were recorded in both experiments and compared with nearby control plots. Both experiments showed that soil water in the TFE declined with time, but tree mortality was similar to that in the control plots during the first 2-3 years. When soil water in the TFE plots fell below an apparent threshold after this period, tree mortality in the TFE plots became 
significantly higher, particularly among tall trees, than in the control plots. The elevated mortality was most likely due to the strongly reduced soil water potential and vulnearability of tall trees to xylem cavitation (Rowland et al. 2015). However, above-ground wood production was already reduced in TFE plots from the second year of throughfall exclusion. Qualitatively these processes support our satellite-based analysis presented here, although the multiple TFE experiments cannot be compared directly with the natural seasonal droughts in 2005 and 2010, as the experiments only reduced soil water without increased surface temperature or atmospheric moisture demand. During the 2005 drought, the accelerated soil moisture depletion may have reduced soil moisture levels below the critical threshold and increase tree mortality. This may be particularly expected in southwestern Amazonia where trees are known to have relatively shallow root systems (Quesada et al., 2011, Quesada et al., 2010).

Our findings help to explain the different rainforest responses in 2005 and 2010 as also observed in the field, but our analysis has limitations of its own. For example, VOD is a dimensionless variable that captures the relative dynamics of canopy water content in Amazonian rainforest as illustrated in this study, but the quantitative relationship between VOD and canopy water content for Amazonian rainforest is not yet known, and we could not quantify the absolute anomalies of canopy water content during the 2005 and 2010 droughts.

\section{Conclusions}

In summary, our study convincingly identified two stages the evolution of the Amazonian droughts of 2005 and 2010. During the onset of droughts in the wet-to-dry season (May-July), below-average rainfall and above-average radiation led to an early arrival of normal dry 
season with enhanced leaf development and ecosystem photosynthesis while there was sufficient soil water. During the peak of droughts in the dry reason (August-October), the drought intensification negatively impacted forest growth and canopy senescence occurred under severe water and heat stress. The magnitude and timing of enhanced canopy growth and subsequent senescence were different for the two droughts. This was primarily caused by the contrasting spatiotemporal evolution in rainfall, radiation and atmospheric moisture demand. Aerosols from biomass burning in the dry season reduced incoming radiation in both years (Artaxo et al., 2013, Ten Hoeve et al., 2012). Without this reduction in radiation, water and heat stress over the intact forests of southern Amazonia might have been even more severe. To better understand the future of the Amazonian rainforests in response to climate change, the interactions between these natural and anthropogenic factors need to be better understood and represented in climate and vegetation models. As demonstrated here, interrogating independent but complementary satellite and field observations can help develop a better understanding of this complex and critical biome.

\section{Acknowledgements}

YYL is a recipient of Thousand Talents Plan for Young Outstanding Scientists, and acknowledges the financial support from the Nanjing University Information Science and Technology (NUIST) startup grant (2243141701020). DGM acknowledges support from the European Research Council (ERC) under grant agreement 715254 (DRY-2-DRY), and the Belgian Science Policy Office (BELSPO) in the framework of the STEREO III programme projects SAT-EX (SR/00/306) and STR3S (SR/02/329). MFM is supported by the King Abdullah University of Science and Technology. PG acknowledges DOE GoAmazon grant 
DE-SC0011094. All authors would like to thank Alexei Lyapustin and Yujie Wang for providing the EVI based on MAIAC algorithm (Collection 6). GRACE land data were processed by Sean Swenson, supported by the NASA MEaSUREs Program and available at http://grace.jpl.nasa.gov. The authors declare no conflict of interest.

\section{References}

Andela, N., Liu, Y.Y., van Dijk, A.I.J.M., de Jeu, R.A.M., \& McVicar, T.R. (2013). Global changes in dryland vegetation dynamics (1988-2008) assessed by satellite remote sensing: comparing a new passive microwave vegetation density record with reflective greenness data. Biogeosciences, 10, 6657-6676.

Aragao, L.E.O.C., Malhi, Y., Roman-Cuesta, R.M., Saatchi, S., Anderson, L.O., \& Shimabukuro, Y.E. (2007). Spatial patterns and fire response of recent Amazonian droughts. Geophysical Research Letters, 34, L07701, doi:10.1029/2006GL028946.

Artaxo, P., Rizzo, L.V., Brito, J.F., Barbosa, H.M.J., Arana, A., Sena, E.T., et al. (2013). Atmospheric aerosols in Amazonia and land use change: from natural biogenic to biomass burning conditions. Faraday Discussions, 165, 203-235.

Atkinson, P.M., Dash, J., \& Jeganathan, C. (2011). Amazon vegetation greenness as measured by satellite sensors over the last decade. Geophysical Research Letters, 38, L19105, doi:10.1029/2011GL049118.

Bi, J., Myneni, R., Lyapustin, A., Wang, Y., Park, T., Chi, C., et al. (2016). Amazon Forests' Response to Droughts: A Perspective from the MAIAC Product. Remote Sensing, 8, 356, doi:10.3390/rs8040356. 
Brando, P.M., Goetz, S.J., Baccini, A., Nepstad, D.C., Beck, P.S.A., \& Christman, M.C. (2010). Seasonal and interannual variability of climate and vegetation indices across the Amazon. Proceedings of the National Academy of Sciences of the United States of America, 107, 14685-14690.

Brando, P.M., Nepstad, D.C., Davidson, E.A., Trumbore, S.E., Ray, D., \& Camargo, P. (2008). Drought effects on litterfall, wood production and belowground carbon cycling in an Amazon forest: results of a throughfall reduction experiment. Philosophical Transactions of the Royal Society B-Biological Sciences, 363, 1839-1848.

da Costa, A.C.L., Galbraith, D., Almeida, S., Portela, B.T.T., da Costa, M., Silva, J.D., et al. (2010). Effect of $7 \mathrm{yr}$ of experimental drought on vegetation dynamics and biomass storage of an eastern Amazonian rainforest. New Phytologist, 187, 579-591.

de Jeu, R.A.M., Holmes, T.R.H., Parinussa, R.M., \& Owe, M. (2014). A spatially coherent global soil moisture product with improved temporal resolution. Journal of Hydrology, 516, 284-296.

Doughty, C.E., \& Goulden, M.L. (2008). Seasonal patterns of tropical forest leaf area index and $\mathrm{CO}_{2}$ exchange. Journal of Geophysical Research: Biogeosciences, 113, G00B06, doi:10.1029/2007JG000590.

Doughty, C.E., Metcalfe, D.B., Girardin, C.A.J., Amezquita, F.F., Cabrera, D.G., Huasco, W.H., et al. (2015). Drought impact on forest carbon dynamics and fluxes in Amazonia. Nature, 519, 78-82.

Feldpausch, T.R., Phillips, O.L., Brienen, R.J.W., Gloor, E., Lloyd, J., Lopez-Gonzalez, G., et 
Fisher, R.A., Williams, M., Do Vale, R.L., Da Costa, A.L., \& Meir, P. (2006). Evidence from Amazonian forests is consistent with isohydric control of leaf water potential. Plant, Cell and Environment, 29, 151-165.

Fisher, R.A., Williams, M., da Costa, A.L., Almeida, S., Meir, P., et al. (2007). The response of an Eastern Amazonian rain forest to drought stress: results and modelling analyses from a throughfall exclusion experiment. Global Change Biology 13, 2361-2378.

Friedl, M.A., Sulla-Menashe, D., Tan, B., Schneider, A., Ramankutty, N., Sibley, A., et al. (2010). MODIS Collection 5 global land cover: Algorithm refinements and characterization of new datasets. Remote Sensing of Environment, 114, 168-182.

Gatti, L.V., Gloor, M., Miller, J.B., Doughty, C.E., Malhi, Y., Domingues, L.G., et al. (2014). Drought sensitivity of Amazonian carbon balance revealed by atmospheric measurements. Nature, 506, 76-80.

Gibbons, J.D., \& Chakraborti, S. (2011). Nonparametric Statistical Inference. (5th Revised Edition ed.). Boca Raton, FL, United States: Taylor \& Francis Ltd.

Guan, K., Pan, M., Li, H., Wolf, A., Wu, J., Medvigy, D., et al. (2015). Photosynthetic seasonality of global tropical forests constrained by hydroclimate. Nature Geoscience, 8, 284-289.

Guglielmetti, M., Schwank, M., Matzler, C., Oberdorster, C., Vanderborght, J., \& Fluhler, H. (2007). Measured microwave radiative transfer properties of a deciduous forest canopy. 
Huffman, G.J., Adler, R.F., Bolvin, D.T., Gu, G.J., Nelkin, E.J., Bowman, K.P., et al. (2007). The TRMM multisatellite precipitation analysis (TMPA): Quasi-global, multiyear, combined-sensor precipitation estimates at fine scales. Journal of Hydrometeorology, 8, $38-55$.

Jackson, T.J., \& Schmugge, T.J. (1991). Vegetation Effects on the Microwave Emission of Soils. Remote Sensing of Environment, 36, 203-212.

Jarvis P G. (1976). The interpretation of the variations in leaf water potential and stomatal conductance found in canopies in the field. Philosophical Transactions of the Royal Society of London. Biological Sciences: Series B, 273, 593-610.

Jiménez-Muñoz, J. C., Mattar, C., Barichivich, J., Santamaría-Artigas, A., Takahashi, K., Malhi, Y., et al. (2016). Record-breaking warming and extreme drought in the Amazon rainforest during the course of El Niño 2015-2016. Scientific Reports, 6, 33130.

Jones, M.O., Jones, L.A., Kimball, J.S., \& McDonald, K.C. (2011). Satellite passive microwave remote sensing for monitoring global land surface phenology. Remote Sensing of Environment, 115, 1102-1114.

Jones, M.O., Kimball, J.S., \& Jones, L.A. (2013). Satellite microwave detection of boreal forest recovery from the extreme 2004 wildfires in Alaska and Canada. Global Change Biology, 19, 3111-3122.

Kerr, Y.H., \& Njoku, E.G. (1990). A semiempirical model for interpreting microwave emission from semiarid land surfaces as seen from space. IEEE Transactions on 
Kirdyashev, K.P., Chukhlantsev, A.A., \& Shutko, A.M. (1979). Microwave Radiation of the Earth's surface in the presence of a vegetation cover. Radio Engineering \& Electronic Physics, 24, 37-44.

Konings, A. G., \& Gentine. P. (2017). Global variations in ecosystem-scale isohydricity. Global change biology, 23, 891-905.

Landerer, F.W., \& Swenson, S.C. (2012). Accuracy of scaled GRACE terrestrial water storage estimates. Water Resources Research, 48, W04531, doi: 10.1029/2011wr011453.

Lee, J. E., Frankenberg, C., van der Tol, C., Berry, J.A., Guanter, L., Boyce, C.K., et al. (2013). Forest productivity and water stress in Amazonia: observations from GOSAT chlorophyll fluorescence. Proceedings of the Royal Society B: Biological Sciences, 280, doi: 10.1098/rspb.2013.0171.

Leuning R. (1995). A critical appraisal of a combined stomatal- photosynthesis model for $\mathrm{C}_{3}$ plants. Plant, Cell and Environment, 18, 339-355.

Lewis, S.L., Brando, P.M., Phillips, O.L., van der Heijden, G.M.F., \& Nepstad, D. (2011). The 2010 Amazon Drought. Science, 331, 554.

Liu, Y.Y., van Dijk, A.I.J.M., de Jeu, R.A.M., Canadell, J.G., McCabe, M.F., Evans, J.P., et al. (2015). Recent reversal in loss of global terrestrial biomass. Nature Climate Change, 5, 470-474.

Liu, Y.Y., van Dijk, A.I.J.M., McCabe, M.F., Evans, J.P., \& de Jeu, R.A.M. (2013). Global vegetation biomass change (1988-2008) and attribution to environmental and human 
Lyapustin, A., Martonchik, J., Wang, Y., Laszlo, I., \& Korkin, S. (2011a). Multiangle implementation of atmospheric correction (MAIAC): 1. Radiative transfer basis and look-up tables. Journal of Geophysical Research: Atmospheres, 116, D03210, doi: 10.1029/2010JD014985.

Lyapustin, A., Wang, Y., Laszlo, I., Kahn, R., Korkin, S., Remer, L., et al. (2011b). Multiangle implementation of atmospheric correction (MAIAC): 2. Aerosol algorithm. Journal of Geophysical Research: Atmospheres, 116, D03211, doi: 10.1029/2010JD014986.

Lyapustin, A.I., Wang, Y., Laszlo, I., Hilker, T., G. Hall, F., Sellers, P.J., et al. (2012). Multi-angle implementation of atmospheric correction for MODIS (MAIAC): 3. Atmospheric correction. Remote Sensing of Environment, 127, 385-393.

Marengo, J.A., \& Espinoza, J.C. (2016). Extreme seasonal droughts and floods in Amazonia: causes, trends and impacts. International Journal of Climatology, 36, 1033-1050.

Meesters, A.G.C.A., De Jeu, R.A.M., \& Owe, M. (2005). Analytical derivation of the vegetation optical depth from the microwave polarization difference index. IEEE Geoscience and Remote Sensing Letters, 2, 121-123.

Morton, D.C., Nagol, J., Carabajal, C.C., Rosette, J., Palace, M., Cook, B.D., et al. (2014). Amazon forests maintain consistent canopy structure and greenness during the dry season. Nature, 506, 221-224.

Nepstad, D.C., Decarvalho, C.R., Davidson, E.A., Jipp, P.H., Lefebvre, P.A., Negreiros, G.H., et al. (1994). The Role of Deep Roots in the Hydrological and Carbon Cycles of 
660

661

662

663

664

665

666

667

668

669

670

671

672

673

674

675

676

677

678

679

Owe, M., de Jeu, R., \& Holmes, T. (2008). Multisensor historical climatology of satellite-derived global land surface moisture. Journal of Geophysical Research: Earth Surface, 113, F01002, doi: 10.1029/2007JF000769.

Owe, M., de Jeu, R., \& Walker, J. (2001). A methodology for surface soil moisture and vegetation optical depth retrieval using the microwave polarization difference index. IEEE Transactions on Geoscience and Remote Sensing, 39, 1643-1654.

Pan, Y.D., Birdsey, R.A., Fang, J.Y., Houghton, R., Kauppi, P.E., Kurz, W.A., et al. (2011). A large and persistent carbon sink in the world's forests. Science, 333, 988-993.

Parinussa, R.M., Yilmaz, M.T., Anderson, M.C., Hain, C.R., \& de Jeu, R.A.M. (2014). An intercomparison of remotely sensed soil moisture products at various spatial scales over the Iberian Peninsula. Hydrological Processes, 28, 4865-4876.

Phillips, O.L., Aragao, L.E.O.C., Lewis, S.L., Fisher, J.B., Lloyd, J., Lopez-Gonzalez, G., et al. (2009). Drought Sensitivity of the Amazon Rainforest. Science, 323, 1344-1347.

Platnick, S., et al. (2015) MODIS Atmosphere L3 Monthly Product. NASA MODIS Adaptive Processing System, Goddard Space Flight Center, USA.

Quesada, C.A., Lloyd, J., Anderson, L.O., Fyllas, N.M., Schwarz, M., \& Czimczik, C.I. (2011). Soils of Amazonia with particular reference to the RAINFOR sites. Biogeosciences, 8, 1415-1440.

Quesada, C.A., Lloyd, J., Schwarz, M., Patiño, S., Baker, T.R., Czimczik, C., et al. (2010). Variations in chemical and physical properties of Amazon forest soils in relation to their 
681

682

683

684

685

686

687

688

689

690

691

692

693

694

695

696

697

698

699

700

Rowland, L., da Costa, A.C.L., Galbraith, D.R., Oliveira, R.S., Binks, O.J., Oliveira, A.A.R., et al. (2015). Death from drought in tropical forests is triggered by hydraulics not carbon starvation. Nature, 528, 119-122.

Saatchi, S., Asefi-Najafabady, S., Malhi, Y., Aragão, L.E.O.C., Anderson, L.O., Myneni, R.B., et al. (2012). Persistent effects of a severe drought on Amazonian forest canopy. Proceedings of the National Academy of Sciences of the United States of America, 110, 565-570.

Saleska, S.R., Didan, K., Huete, A.R., \& da Rocha, H.R. (2007). Amazon forests green-up during 2005 drought. Science, 318, 612.

Saleska, S.R., Wu, J., Guan, K., Araujo, A.C., Huete, A., Nobre, A.D., et al. (2016). Dry-season greening of Amazon forests. Nature, 531, E4-E5.

Samanta, A., Ganguly, S., Hashimoto, H., Devadiga, S., Vermote, E., Knyazikhin, Y., et al. (2010). Amazon forests did not green-up during the 2005 drought. Geophysical Research Letters, 37, L05401, doi:10.1029/2009GL042154.

Santi, E. (2010). An application of the SFIM technique to enhance the spatial resolution of spaceborne microwave radiometers. International Journal of Remote Sensing, 31, 2419-2428.

Seager, R., Hooks, A., Williams, A.P., Cook, B., Nakamura, J., \& Henderson, N. (2015). Climatology, Variability, and Trends in the U.S. Vapor Pressure Deficit, an Important Fire-Related Meteorological Quantity. Journal of Applied Meteorology and Climatology, 
Swenson, S., \& Wahr, J. (2006). Post-processing removal of correlated errors in GRACE data. Geophysical Research Letters, 33, L08402, doi: 10.1029/2005GL025285.

Ten Hoeve, J.E., Remer, L.A., Correia, A.L., \& Jacobson, M.Z. (2012). Recent shift from forest to savanna burning in the Amazon Basin observed by satellite. Environmental Research Letters, 7, 024020, doi:10.1088/1748-9326/7/2/024020.

Toomey, M., Roberts, D.A., Still, C., Goulden, M.L., \& McFadden, J.P. (2011). Remotely sensed heat anomalies linked with Amazonian forest biomass declines. Geophysical Research Letters, 38, L19704, doi:10.1029/2011GL049041.

Wielicki, B.A., Barkstrom, B.R., Harrison, E.F., Lee, R.B., Louis Smith, G., \& Cooper, J.E. (1996). Clouds and the Earth's Radiant Energy System (CERES): An Earth Observing System Experiment. Bulletin of the American Meteorological Society, 77, 853-868.

Wu, J., Albert, L.P., Lopes, A.P., Restrepo-Coupe, N., Hayek, M., Wiedemann, K.T., et al. (2016). Leaf development and demography explain photosynthetic seasonality in Amazon evergreen forests. Science, 351, 972-976.

Xu, L.A., Samanta, A., Costa, M.H., Ganguly, S., Nemani, R.R., \& Myneni, R.B. (2011). Widespread decline in greenness of Amazonian vegetation due to the 2010 drought. Geophysical Research Letters, 38, L07402, doi:10.1029/2011GL046824, 2011

Yan, K., Park, T., Yan, G., Chen, C., Yang, B., Liu, Z., et al. (2016a). Evaluation of MODIS LAI/FPAR Product Collection 6. Part 1: Consistency and Improvements. Remote Sensing, 8,359 . 
722

723

724

725

726

727

728

729

730

731

732

733

734

735

736

737

738

739

740
Yan, K., Park, T., Yan, G., Liu, Z., Yang, B., Chen, C., et al. (2016b). Evaluation of MODIS LAI/FPAR Product Collection 6. Part 2: Validation and Intercomparison. Remote Sensing, 8, 460.

Zhou, L., Tian, Y., Myneni, R.B., Ciais, P., Saatchi, S., Liu, Y.Y., et al. (2014). Widespread decline of Congo rainforest greenness in the past decade. Nature, 509, 86-90. 
742

743

744

745

746

747

748

749

750

751

752

753

754

755

756

757

758

759

760

761

Fig 1. Spatial distribution of vegetation characteristics over the study area. (a) Land cover map (at $0.10^{\circ}$ spatial resolution) over Amazonia based on the $0.05^{\circ}$ MODIS IGBP classification product for 2010. 'Intact forest' means that all four $0.05^{\circ}$ grid cells in one $0.10^{\circ}$ grid cell are classified as forest. (b) The 'intact forest' in southern Amazonia $\left(2.5^{\circ} \mathrm{S}-12.5^{\circ} \mathrm{S}\right.$, $75^{\circ} \mathrm{W}-50^{\circ} \mathrm{W}$ as outlined) is the study area of this paper. The annual average VOD value at $0.10^{\circ}$ spatial resolution is displayed in the background. A brief comparison between the downscaled $\left(0.10^{\circ}\right)$ and original $\left(0.25^{\circ}\right)$ VOD data can be found in Fig. S1.

Fig 2. Hydrometeorological dynamics over southern Amazonia during non-drought years. Seasonal cycles of rainfall $\left(\mathrm{P}, \mathrm{mm} \mathrm{month}^{-1}\right)$, photosynthetically active radiation (PAR, W $\mathrm{m}^{-2}$ ), aerosol optical depth (AOD), cloud optical thickness (COT), terrestrial water storage (TWS, mm), land surface temperature (LST, K) and vapor pressure deficit (VPD, kPa) over the intact forest region in southern Amazonia during non-drought years (i.e., averaged over 2003-2010, excluding 2005 and 2010). The anomalies in 2005 and 2010 will be examined in detail over the extended dry season (May-October) that is outlined by the blue box.

Fig 3. Hydrometeorological anomalies over southern Amazonia in the 2005 and 2010 droughts. Time series of monthly average (a) rainfall (P), (b) photosynthetically active radiation (PAR), (c) aerosol optical depth (AOD), (d) cloud optical thickness (COT), (e) terrestrial water storage (TWS), (f) land surface temperature (LST) and (g) vapor pressure deficit (VPD) over southern Amazonia from May through October in 2005 and 2010 in comparison with non-drought years, respectively. 
Fig 4. Anomalies in rainfall $(\mathrm{P}, \mathrm{mm})$ and photosynthetically active radiation $\left(\mathrm{PAR}, \mathrm{W} \mathrm{m}^{-2}\right.$ ) for the onset of drought during the wet-to-dry season (May-July) and the peak of drought during the dry season (August-September) of 2005 and 2010. Anomalies represent the departure from the average of non-drought years. The areas with statistically significant anomalies based on non-parametric Wilcoxon signed rank test $(p<0.05)$ are hatched.

Fig 5. Standardized anomalies in vegetation indicators during the onset of droughts (May-July) in 2005 and 2010. Units represent the number of standard deviations as a departure from the average of non-drought years in (a and b) night-time vegetation optical depth (VOD), (c and d) leaf area index (LAI), and (e and f) enhanced vegetation index (EVI). Areas with statistically significant anomalies based on the non-parametric Wilcoxon signed rank test $(\mathrm{p}<0.05)$ are hatched.

Fig 6. (a and b) Mean TWS over May-July minus TWS $_{M I N}$ during the non-drought years for each grid cell ( $\Delta$ TWS). (c and d) Mean LST over May-July minus LST MAX $_{\text {during the }}$ non-drought years $(\triangle \mathrm{LST})$. (e and f) Mean VPD over May-July minus VPD $\mathrm{MAX}_{\mathrm{X}}$ during the non-drought years $(\triangle \mathrm{VPD})$.

Fig 7. Standardized anomalies in night-time VOD during the peak of droughts (August-October) in 2005 and 2010. Units represent the number of standard deviations as a departure from the average of non-drought years. Areas with statistically significant anomalies based on non-parametric Wilcoxon signed rank test $(p<0.05)$ are hatched.

Fig 8. ( $a$ and b) Mean TWS over August-October minus TWS $_{\text {MIN }}$ during the non-drought years for each grid cell ( $\triangle$ TWS). (c and d) Mean LST over August-October minus LST MAX 

VPD $_{\text {MAX }}$ during the non-drought years $(\Delta V P D)$. ( $g$ and $\left.h\right)$ Total number of months with

785 monthly rainfall below $100 \mathrm{~mm}$ and significantly below average of non-drought years, 786 between May and October in 2005 and 2010 respectively for each grid cell. 